This is the final peer-reviewed accepted manuscript of:

Romandini M, Terlato G, Nannini N, Tagliacozzo A, Benazzi S, Peresani M. Bears and humans, a Neanderthal tale. Reconstructing uncommon behaviors from zooarchaeological evidence in southern Europe. J. Archaeol. Sci. 90, 71-91 (2018).

The final published version is available online at: https://doi.org/10.1016/i.jas.2017.12.004

(C) 2017. This manuscript version is made available under the Creative Commons AttributionNonCommercial-NoDerivs (CC BY-NC-ND) License 4.0 International

(http://creativecommons.org/licenses/by-nc-nd/4.0/) 


\title{
Bears and Humans, a Neanderthal tale. Reconstructing uncommon behaviors from zooarchaeological evidence in Southern Europe.
}

Matteo Romandini ${ }^{1-2}$, Gabriele Terlato $^{2-3}$, Nicola Nannini ${ }^{2-4}$, Antonio Tagliacozzo ${ }^{5}$, Stefano Benazzi $^{1}$, Marco Peresani ${ }^{2 *}$

${ }^{1}$ Dipartimento di Beni Culturali, Università di Bologna, Via degli Ariani 1, 48121 Ravenna, Italy.

${ }^{2}$ Università degli Studi di Ferrara, Dipartimento di Studi Umanistici, Sezione di Scienze Preistoriche e Antropologiche, Corso Ercole I d'Este, 32, Ferrara.

${ }^{3}$ Area de Prehistoria, Universitat Rovira i Virgili (URV), Avinguda de Catalunya 35, 43002 Tarragona, Spain.

${ }^{4}$ MuSe - Museo delle Scienze, Corso del Lavoro e della Scienza 3, IT 38123, Trento, Italy

${ }^{5}$ Polo Museale del Lazio, Museo Nazionale Preistorico Etnografico "L. Pigorini”, Sezione di Bioarcheologia, Piazzale G. Marconi 14, I-00144 Rome, Italy.

E-mail: matteo.romandini@unibo.it; gabriele.terlato@gmail.com; nicola.nannini@unife.it; antonio.tagliacozzo@beniculturali.it; stefano.benazzi@unibo.it; marco.peresani@unife.it

* corresponding author

\begin{abstract}
Cave bear (Ursus spelaeus), brown bear (Ursus arctos), and Neanderthals were potential competitors for environmental resources (shelters and food) in Europe. In order to reinforce this view and contribute to the ongoing debate on late Neanderthal behavior, we present evidence from zooarchaeological and taphonomic analyses of bear bone remains discovered at Rio Secco Cave and Fumane Cave in northeast Italy, an extended geographic area north of the Adriatic Sea. The remains from both caves come from layers dated to 49-42 ky cal. BP, and suggest close interactions between humans and bears, with data not only limited to the association of Mousterian lithic artifacts with
\end{abstract}


numerous bear remains, but also the detection of clearly preserved traces of human modification such as cut and percussion marks, which enable a reconstruction of the main steps of fur recovery and the butchering process. Examples of Neanderthal bear exploitation are extremely sporadic in Europe, and Grotta Rio Secco and Grotta Fumane can be considered rare cases of remain accumulations generated by the human predation of bears of varied age classes during or near the end of hibernation. All of this evidence suggests that bears had a strategic role in the nomadic economy of Neanderthal hunting groups.

Key-words: Cave bear, Brown bear, Middle Palaeolithic, Hunting, Taphonomy, Cave, Italy

\section{Introduction}

From the Middle to the Upper Pleistocene, humans and bears coexisted and cohabitated in a good part of Europe. This is demonstrated by numerous findings of plantigrade remains in association with artifacts, interpreted over the course of the 20th century to demonstrate both the hunting of these carnivores and the accumulation of their bones following natural deaths in contexts that also indicate anthropic frequentations (Fedele, 1968; Jéquier, 1975; Hille and Rabeder, 1986; Tillet, 1997; Le Tensorer, 1998; Tillet and Bernard-Guelle, 1998; Fosse et al., 2002; Auguste, 2003; Bona et al., 2007; Torres et al., 2007; Cvetković and Dimitrijević, 2014; Bocherens et al., 2014; Fourvel et al., 2014). However, the taphonomic history of these faunal assemblages within caves is very complex and has only been refined in the last 20 years by microscopic and taphonomic investigative techniques, accompanied by reviews of the materials excavated in the early to middle of the last century that have shown that between these large carnivores and Neanderthals, a consolidated and probably "symbiotic" interactive relationship was established (Koby, 1951; Kurten, 1976; Fosse et al. 2002; Stiner, 1998; Auguste, 2003). The ecological and etological characteristics shared by humans and ursids (Ursus arctos and Ursus spelaeus) were not, in fact, insignificant. Besides 
adopting prey acquisition and related alimentary regime strategies, they shared habitat types and shelters, which were utilized for hibernation and protection, especially of the youngest (Turner 1992, 1994; Arribas and Palmqvist, 1999; Hemmer, 2000; Brugal and Fosse, 2004), whose distribution and density is equally a regulating factor within species assemblages that can live in territorial or family communities. Human and bear interactions are particularly observed in Europe throughout the Upper Pleistocene, with abundant ursid populations and numerous Mousterian frequentations attested by archaeological finds in caves and shelters (Petram, 2004; Bona et al., 2007; Diedrich, 2012; Viranta and Grandal d'Anglade, 2012). In terms of contributing factors to the overall interaction, climatic conditions had greater impact in respect to the more temperate regions, which were differentiated by environments, types of vegetation, geological substrates, and by populations and the structure of ursid communities (Turner, 1995). Lastly, the quality of the fossil record and the level of archaeozoological and taphonomic research must also be considered.

The sizes of Ursus arctos and Ursus spelaeus, averaging 260 and $600 \mathrm{~kg}$, respectively, are markedly different, but their eto-ecological behaviours are very similar. With a longer life span among the carnivores (20-30 years), these ursids were adapted to temperate-cold climes, preferring semiforested vegetation, and could live in groups or individually, moving through a territory estimated to between 100 and 1,000km2 for females and males, respectively, (Caloi et al., 1997; Couturier, 1954; Jakubiek, 1993; Brugal et al., 2001; Brugal and Fosse, 2004; Torres et al., 2007). The dimensions of the ursid groups, their structural stability, and the size of their populations are in most cases strongly influenced by the presence of water, which determines the choice of a suitable place of refuge, the abundance of herbivorous prey, and even, for mothers and young, the orientation of slopes (S, S-E), fundamental to the micro-climatic conditions in the critical phases of hibernation.

If one talks of taphonomy and archaeozoology in relation to the ursids, it is impossible not to take into consideration the theory of the "Bear Cult," which was widely diffused in the first half of the 20th century by Emil Bächler (Bächler, 1920-1921, 1923, 1940), who hypothesized the existence of 
a culture unique to the Alps, associated to the Riss-Würm Interglacial: the "Palaeolithic" or "Alpine Mousterian." This "culture" was associated with a specialized hunting of young cave bears that was practiced in the summer at highland sites where, in addition to bear remains, bone tools and lithic industries were identified at the time, often described as Quina Mousterian type. The true "Bear Cult," "Cave Cult," and/or "Cult of Hunting and Sacrifice" (Bächler, 1920-1921) is manifested through the presumed deposition or replacement of cave bear long bones and crania. These theories or hypotheses saw undeniable comparisons in archaeological evidence from Germany, Austria, Hungary, Slovenia, and Croatia (Pacher, 2003). Decades later, the theory of the "Bear Cult" was totally abandoned by challenging the origin and anthropic modification of bear remains (Koby, 1943, 1951, 1953; Kurten, 1976; Fosse et al., 2002; Stiner, 1998; Auguste, 2003).

However, aside from the discussed practice of burying human remains in association with brown bear bones as funerary goods at Le Régourdou in France (Cavanhié, 2009-2010), many examples linking Neanderthals and bears are now known thanks to the discovery of lithic tool cut-marks on the surfaces of ursid bones from recently excavated sites or from review of ancient excavation materials. At Taubach, the systematic destruction of $80 \%$ of the brown bear canines (Kurten, 1976), based on the current state of knowledge, cannot be explained by the vague term "symbolic," as in the majority of cases it is "utilitarian." The main difficulty, then, lies in evaluating the degree active hunt against scavenging. The hypotheses of carcass manipulation at the bears' natural place of death seems plausible for the Mousterian: evidence for such behavior has been observed in Belgium at Goyet and Scladina caves (Germonpré and Sablin, 2001; Germonpré and Hämäläinen, 2007; Abrams et al., 2014), in France at Regourdou (Cavanhié, 2009-2010; Bonifay et al., 2007), in Germany at Geißenklösterle, Hohle Fels and Balve Cave (Kitagava et al., 2012; Münzel, 1997; Münzel and Conard, 2004b; Münzel et al., 2011; Kindler, 2012), in Austria at Salzofen Cave (Ehrenberg 1958-59, cited by Armand et al., 2004), in Poland at Nietoperzowa (Wojtal, 2007; Wojtal et al., 2015), in Slovenia at Divje Babe (Turk, 1997; 2014), in Serbia at Pešturina Cave (Majkić et al, 2017), in Montenegro at Crvena Stijena (E. Morin personal communication) and in 
Italy at Caverna delle Fate, Madonna dell'Arma, Ciota Ciara, Badalucco, Le Manie, and Sant'Agostino (Stiner, 1994; Valensi and Psathi, 2004; Quilès, 2003, 2004; Buccheri et al., 2016) (Fig. 1, Tab.1). In light of these findings, it is thus possible to distinguish two principal European regions of Neanderthal ursid exploitation from OIS6 to OIS-3: one in north-central Europe (Germany, France, and Belgium), and one in the central-eastern Mediterranean (northern Italy and the Balkans) (Fig. 1, Tab. 1).

Within a framework that addresses rather fragmented and patchy taphonomic evidence, this work seeks to reinforce this view through the presentation of two cave contexts, Rio Secco Cave (Grotta de Rio Secco) and Fumane Cave (Grotta di Fumane) in the Italian Alps, which are geographically distant but chronologically related, and that provide several distinct Neanderthal frequentations that attest to the systematic and consolidated exploitations of bears (Ursus arctos and Ursus spelaeus).

\section{FIGURE 1, TABLE 1 AND FIGURE 2 ABOUT HERE}

\section{The use of cavities by bears}

"Bear sites" are characterized by a percentage of bear remains within caves or shelters equal to 80$99 \%$ of the total recovered bones (Quilès, 2004), "charriage a sec" (Koby 1941-1943; Andrews and Turner, 1992) on the bone surface, traces of frequentation (including claw marks and polishing of the cave walls), and/or the presence of "bear earth," rich in phosphate nodules derived from the decomposition of their carcasses (equaling $10-17 \mathrm{~kg}$ of phosphate per individual). Bear caves can be divided into "bear hibernation den" and "cave/shelter den." These attributions are secondary to the function of the cave and the identity of its occupants: bear (male adults or females with cubs and young), carnivore, or man (Quilès, 2004). Other parameters include the representative indexes of bone destruction and the proportions of axial skeletons. In the "bear hibernation den," the appendicular skeleton will be strongly represented, in some cases with intact skeletons recovered in 
anatomical connection. The "cave/shelter den", however, is characterized by a major percentage of bone destruction and dispersal due to continuous trampling over a lesser occupational duration.

The ratio of cave bear remains to other animals in bear sites and the ratio of cave bear to brown bear remains appears to be 10:1, if not higher (Quilès, 2004). Both the cave bear and modern bears appear to be long-lived animals with a low reproductive success that rarely confers to their respective populations a high density. This is due to factors of an ecological order, such as trophic capacity, living space, infant mortality rate, and, in modern populations, human disturbances, either direct or indirect. According to studies carried out in North America, females grizzly give birth on average every two to three years, and individuals of both sexes, at a ratio of 1:1, are considered fertile at around the age of four to five years (Craighead et al., 1974). Females are fertile until the age of 18 and the number of cubs born is usually one or two, rarely three or four. The mating period for European brown bears is around the months of May and July, while the American grizzly mates between June and August. The gestation period varies from seven to eight months. At birth, which takes place between January and March in various species (during the wintering), the cubs weigh 250-400g, about $1 / 500$ of the female's weight. The bear spends the cold season sheltered in refuges (dens) in semi-hibernation, a torpor produced by a more or less prolonged state of sleep induced by low temperature and the length of photoperiod. This state of immobility is achieved gradually in the den two to three weeks after entrance: during this transitional period, and even when slumber is reached, the bear is able to temporarily resume activity. During hibernation, which lasts for 4-5 months, the animal's metabolism is very slow: the state of fasting is complete (excrement and urine in dens or in the vicinity thereof have not been found in the current bear populations). According to observations made of grizzlies in a state of induced hibernation (Watts and Jonkel, 1988), a bear weighing $200 \mathrm{~kg}$ consumes a quantity of fat of about $50 \mathrm{~kg}$ during or almost six months of inactivity period, an average rate of about $400 \mathrm{~g}$ /day. The resumption of normal metabolic activity occurs gradually; immediately after the exit from the den, the movements are limited to patrolling the wintering area. The female usually leaves her den only when the cubs are able to walk. Mortality in 
modern bears tends to be cyclical, and occurs especially in the period at the end of hibernation. Hunger is the most common cause of death of individuals during hibernation, especially cubs and young individuals, while adults rarely perish for this reason, anticipating awakening if their energies are exhausted and the search for food sources becomes imperative. If these aims are not achieved, death occurs in the territory around the wintering site. Juveniles or young adults may also be particularly vulnerable at the moment of or prior to awakening from hibernation and at the gradual resumption of activities when the mother leaves to explore the hibernation range.

\section{This study: materials and methods.}

The bear bones examined in this study have been discovered at Rio Secco Cave and Fumane Cave, mostly in the last decade of excavations (see SI). Taxonomic and skeletal identifications are based on the complete alpine fauna reference collection from the Department of Humanities at the University of Ferrara, featuring Pleistocene and modern fauna with reliable chronological attribution. Regarding the analysis of age groups, many studies have documented how the approximate age at death of cave bears may be inferred from the stages of dental development or occlusal wear (Kurten, 1958; Dittrich, 1960; Torres, 1976, 1984, 1988; Stiner, 1998; Torres et al., 2007). The "tooth eruption wear stages" Stiner, 1998; Fosse and Cregut-Bonnoure, 2014) and epiphyseal fusion (Weinstok, 2009) were the methods taken into consideration for the allocation of individuals' age.

The bone surfaces were analyzed both macroscopically and microscopically using a small magnifying lens (10-20x) with incident white light and a Leica S6D Greenough stereo microscope with $0.75-70 \mathrm{X}$ magnification range for capturing images. Further qualitative data were collected via SEM observations at the MUSE (Science Museum of Trento) using a ZEISS EVO XVP microscope, at high vacuum on gold-coated prepared resin replica (Araldite LY554 with HY956 hardener to $20 \%$ weight). In order to identify the nature of surface alterations and to distinguish 
human from animal traces, trampling abrasion, and modern mechanical modifications produced by excavation tools, reference was made to well-established taphonomic literature. Combustion degree has been distinguished between moderate $\left(200-500^{\circ} \mathrm{C}\right.$, black/brown) and elevated with calcination ( $>700{ }^{\circ} \mathrm{C}$, grey/white) (Stiner et al., 1995; Costamagno et al., 2005). Cut-marks have been classified as incisions, like skinning marks, defleshing marks, and scrapes (Binford, 1981; Potts and Shipman, 1981; Shipman, 1981; Shipman and Rose, 1984). The documented incisions appear linear, with great variability in length, width and depth, V-shaped section, and internal microstriation at the base of the groove. Attention was paid to differentiating between trampling and butchery marks (Domìnguez-Rodrigo et al., 2009). Recording the localization of trampling striae on the bone yields indirect information on the extent of animal occupation at the site (Koby, 1941-1943). Intentional bone breakage to access marrow was documented by diagnostic elements like percussion marks/notches and impact flakes, and positive flakes of the percussion marks (Blumenschine and Selvaggio, 1988; Villa and Mahieu, 1991; Capaldo and Blumenschine, 1994; Pickering and Egeland, 2006).

Regarding the traces left by carnivores, these were identified as deep punctures in the cortical bone surface, concentrated on the articular ends of the bones, as well as pits and scores with U-shaped striations on bone surfaces. These results were compared with data from Fisher (1995), Selvaggio and Wilder (2001), Domìnguez-Rodrigo and Piqueras (2003), Diedrich (2012), Fourvel et al. (2014) and Camarós et al. (2017), The analysis of modifications left by carnivore gnawing also included traces left by human teeth, which were documented and compared with the data from Landt (2007), Fernández-Jalvo and Andrews (2011), and Saladie et al. (2013). Potential burnt bones were determined by combustion grade level following the criteria described by Stiner et al. (1995). Evidence of anthropic peeling by flexion (Pickering et al., 2013) on some elements at Rio Secco Cave is clearly differentiated from peeling associated with carnivore mastication events (Arilla et al., 2014). 
According to the analytical protocol, natural post-depositional degradations have been searched for only on bones longer than $3 \mathrm{~cm}$ or on bone relevant at the taxonomical level. Smoothed bone edges and root grooves have been ascribed to biological as well as several physical processes.

In order to evaluate species abundance, number of remains (NR) (Grayson, 1984), minimum number of elements (MNE) (Binford, 1981; Klein and Cruz-Uribe, 1984; Stiner, 1994), and the minimum number of individuals (MNI) (Bökönyi, 1970) were used. The age range estimates (Tab. 5) included five age groups: I (Infant, 0-1 years); Y (Young, 1>4 years); Y-AD (Young-Adult, 4>8 years); A (Adult, $8>20$ years); S (Senile, 20>30 years). The fragmentation index (MNE/NISP) and the coefficient of the survival of the anatomical elements were calculated by dividing the minimum number of elements (MNE) for the number of elements expected (MNE/NEE). NEE was factored as if the carcasses had been transported whole to the site. To achieve broad indirect indicators of human-bear interactions, although combined with the above-described taphonomic type of evidence, carnivore-herbivore ratios (Enloe, 2012) have also been calculated for each archaeological layer investigated.

\section{Results}

The Rio Secco Cave archaeological investigations have so far been conducted on about $18 \mathrm{~m}^{2}$ of the Mousterian occupation levels $(5$ top +7 and 5+8) and the analyses of the faunal remains are still ongoing (see SI). In both levels, the differences in the conservation of fossorial animal remains (Marmota marmota) are easily visible, macroscopically evident by their fresher aspects in respect to the remains ascribable to the Middle Paleolithic levels. Taphonomic agents such as roots, manganese oxidesroots, and concretions are present in less than $9 \%$ of the marmot bones (n. 300). In the total faunal assemblage, bone surfaces are well preserved: $32 \%$ of bone remains bear root etching, while on other fragments micro-fissures result from weathering phenomena. Rodent gnaw marks are almost absent $(n=43)$, while carnivore marks, in the form of scoring, pits, or gastric juice 
erosion, were detected only on 86 specimens. In 5 top +7 , while the bone assemblage is fragmentary (total no. $52483.2 \%<3 \mathrm{~cm} ; 16.8 \%>3 \mathrm{~cm}$ ), the high percentage (NISP 376, higher than 70\%) of the number of determined individuals (Tab. 2) is certainly influenced by the quantity of carnivore remains (NISP 249), equal to 66.2\%, and the instance of ursids (NISP 220), equal to 58.2\%, which are more easily determinable thanks to the dimension, structure, and greater resistance to mechanical strength of the bones. In layers $5+8$, such determinations cannot be made: from a total of 4,301 analyzed remains, $13.5 \%$ (NISP 582) of remains were determined at the level of species, genus, or family; of these, 257 (44.1\%) were marmots intruding into the Mousterian sequence, while 222 ursids $(38 \%)$ reveal high fragmentation $(11.9 \%<3 \mathrm{~cm} ; 88.1 \%>3 \mathrm{~cm})$. Excluding the marmots, the most represented animal is Ursus spelaeus, at $39.3 \%$ of the remains in 5 top +7 and $27 \%$ of $5+8$, followed by small elements of Ursus arctos, at $1.6 \%$ and $0.2 \%$, respectively. In both layers, from a total of 130 remains (Ursus sp.), nearly equally subdivided between the two stratigraphic assemblages, it was not possible to precisely attribute taxonomy to either $U$. arctos or U. spelaeus (Tab. 2).

At Fumane Cave, excavations have covered around $65 \mathrm{~m}^{2}$ of the A5-A6 stratigraphic assemblage (see SI). The high fragmentation of bone remains $(4.6 \%<3 \mathrm{~cm} ; 96.4 \%>3 \mathrm{~cm})$ limited the number of determined remains NISP $=836$, equal to $1.4 \%$ of the 60,494 total (Tab. 2 ). This is also the case in A6, where of the 110,777 analyzed remains, $2,274(2 \%)$ were determinable at a specific level. The ursid remains totaled 19 (2.2\%) in A5-A5+A6 and 31 (1.4\%) in A6 (Tab. 2). For the most part, in both levels it was not possible to certainly identify taxonomic attribution to $U$. arctos and/or $U$. spelaeus (Total no. U. sp.=34). Overall, despite the small number of determined remains, it is clear that the brown bear $(n=4$ in $A 5-A 5+A 6 ; n=10$ in A6) is better represented in respect to the cave bear $(n=2)$, of which a rib and a proximal portion of the ulna were isolated exclusively in A5-A5+A6.

\section{TABLE 2 ABOUT HERE}




\subsection{Taphonomy}

\section{$\underline{\text { Rio Secco Cave }}$}

In levels 5 top +7 and $5+8$, the bear remains reporting evident traces of butchery marks are abundant (Tab. 3), numbering $47(21.4 \%)$ and 34 (15.3\%), respectively. These are observed as isolated or as series of cuts, testifying to short and medium-length gestures; however, only in 5top +7 scraping is observed (Fig. 3A and Fig. 4A_1).

Percussion marks (PM) on long bones for the extraction of marrow are around $10.6 \%$ and $11.8 \%$ of the total remains with traces (Tab. 3), respectively per frequentation phase, and in some cases are accompanied by cut-marks (CM) from lithic tools. In general, in comparing the two frequentation levels at Rio Secco, a certain equilibrium in the processing of bear carcasses is observed (Fig. 3A and B). The most intense traces are around the ribs and the anterior and posterior limbs (Tab. 3, Fig. 3A and B), which refer (in order of frequency), to skinning, defleshing and the removal of muscle mass, disarticulation, and the percussion and combustion/burning of bones (burned remains $11.3 \%$ and 5.8\%) (Tab. 3, Fig. 3A and B).

\section{TABLE 3 AND FIGURE 3 ABOUT HERE}

Some phalanges (Nr. 2, Fig. 4I) show short, persistent cut-marks, transversal to the major axis of the element, testifying to the first phases of fur recovery. The anterior and posterior limb elements from the two investigated levels show that these were targeted anatomical parts for muscle removals (Tab. 3, Fig. 4, and Fig. 6), while radii and ulna, in the proximal portions, bear major evidence of anthropic activity linked to the removal of bicep and tricep muscles and the severing of flexors and tendons from the main articulations of the forearm (Fig. 4A-E and Fig. 6D-F). Femurs, tibiae, and a fibula (Tab. 3) show actions respective to the removal of the vastus intermedius muscle, the grand adductor of the thigh, and the flexor or extensor of the digits (Fig. 4G-H and Fig. 6G-I). For both levels the anterior and posterior limbs show the highest percentage of BM and an 
intentional extraction of marrow, with the radius and humerus with between 50 and $67 \%$ and the femur and tibia between 39 and 46\% (Tab. 3, Fig. 4F and Fig. 6G). It should, however, be clarified that in some cases, for certain anatomical elements where the bone is less protected from the muscular tissue, cut-marks may also refer to the recovery of skin or to disarticulation (Fig. 4C and I, Fig. $6 \mathrm{H})$. In more than one case it is clear that the age of the butchered individuals is Young $(\mathrm{n}=5)$ or even Infant ( $\mathrm{n}=1$, about 8-12 months).

\section{FIGURES 4 and 5 ABOUT HERE}

The quality of the different types of anthropogenic traces recognized on the rib elements (Fig. 5, 6, and 10) enables many actions performed by Neanderthals on ursid carcasses to be detailed (Tab. 3 ). Both archaeological levels show a high number of cut-marks on the dorsal and ventral surfaces of many ribs, which in most cases are presented as short, persistently deep, and transverse to the major axis. In those cases where cut marks are positioned in lateral pattern (skull-caudal), the consequent detachment of the serratus muscles, latissimus dorsi, external oblique muscle of abdomen, thoracic serratus ventralis, serratus anterior, or intercostal muscles can be hypothesized, but it cannot be excluded that some traces may have been impressed during the phases of skin detachment from this anatomical region (Fig. 5, 6B-C and Fig. 10A). Less frequently, the presence of cut-marks on the medial (or ventral) surface, also in proximity to the epiphyses, can describe attempts to sever the levatores costarum muscle or to overcome the resistance of articulation with the spinal column (Fig. 5C). The desire to obtain diaphyseal portions of the rib cage is clear and documented for now only in 5top +7 (Fig. 5C-D) by evident traces of peeling (Tab. 3, n. Pe $=6$ ), which were produced by flexing the element in a fresh state in a direction opposite to the articulation of the bone (Pickering et al., 2013). Confirming the particular interest for ribs, four diaphyses from the two levels of Mousterian frequentation furthermore show their use as retouchers (Fig. 10 and Tab. 6), while in other cases localized combustion is present, some of which is posterior to peeling and/or are 
associated with cut-marks (Fig. 5C). The search for muscle groups (e.g. transversospinalis) is demonstrated by medium to long cut-marks on the dorsal face of the vertebral arch, at the base of the spinous processes of some vertebrae (Fig. 6F).

From the cranial region, a portion of masseteric fossa and portions of the condyloid process of a right hemimandible from an adult Ursus spelaeus individual show clear cut-marks, which are oblique to the longitudinal axis of the element and present on the interosseous space that divides the angular process from the neck of the condyle (Fig. 6A_1+1a). The intention might be to remove the masseter muscle and possibly to disarticulate the jaw from its seat, as shown by extensive peeling (Tab. 3 and Fig. 6A), which is visible in the medial view and is also accompanied by clear combustion.

As for the modes of limb exploitation, these are typified by the cut-marks presented on a right, semi-complete cave bear scapula. The element was clearly disarticulated from the trunk, isolated or in connection with the stylopod. Short and persistent as well as long and isolated cut-marks are clearly visible both in the dorsal and the ventral view. In the medial view, transversal-oblique cuts present on the supraspinous fossa are of short and medium length and clearly distinguish and document the detachment of the homonymous muscle (Fig. 7A_1-3). In medial pattern (ventral), short, single, or groups of cut-marks with varying orientation are concentrated on the subscapular fossa (Fig. 7B_4-5), while some, shorter and more persistent, can be noted on the neck at the base of the articular epiphyses. All of these gestures in these patterns are attributable to the detachment of the extended subscapular muscle. It is important to note that in correspondence to the bitemark area, part of the supraspinous fossa is involved also with external combustion (Fig 7B_6). In general, at Rio Secco there are many bear remains that present traces of combustion, extensive or localized, isolated or in association with cut-marks, peeling, and/or percussion marks (See SI; Tab. 3, Fig. 4-7). It is noted that the near totality of the anatomic elements on which traces of anthropic origin are recognized are almost always associated with combustion (Tab. 3). 
FIGURES 6 AND 7 ABOUT HERE

\section{$\underline{\text { Fumane Cave }}$}

In levels A5-A5+A6 and A6, ursid report evident traces of butchery (Tab. 3), numbering 6 (30\%) and $10(32.2 \%)$. The cuts appear isolated or in series, are of short or medium length, and only present as scrapes (Fig. 8C_4) or percussion marks $(n=2)$ in A6, resulting from intentional fracturing aimed at the consumption/removal of marrow (Fig. 8D). While recalling the small presence of axial skeleton remains, these findings nonetheless emphasize how the traces related to the treatment of the carcass, which in both cases are exclusively concentrated on elements of the limbs and their extremities (Tab. 3, Fig. 3C-D). Some phalanges, sesamoids, and a metatarsal (Fig. 8H_8 and G_7; Fig. 9D_11 and C_9; Fig. 10F_8) show short cut-marks, which are sometimes deep and persistent and transversal and oblique to the major axis of the element, attesting to some of the early phases of fur recovery. The defleshing and detachment of muscle mass is evident: two radii from different individuals, two femurs, a tibia, and a fibula from adult specimens, and an ulna of Ursus spelaeus, indicate actions that must have been intended first to detach the muscles and then to deflesh the remnants (Fig. 8A_1+1a and C_4, B_2+3; Fig. 9A_1+5, B_6+7). For certain anatomical elements, the cut-marks can persist where the soft tissues around the bone are thinner (proximal and distal parts of the ulna and radii), and therefore these refer also to some of the phases of hide recovery. As an example, the cut-marks present on a lateral diaphysis of a left fibula can be attributed to both the detachment of the lateral extensor muscles of the digits and/or the peroneus brevis at some stages of fur removal (Fig. 8B_2+3). Percussion marks are visible on a diaphyseal portion of a femur and an ulnar medial diaphysis (Fig. 8D and Fig. 10E_7). In both levels, disarticulation is documented by two tarsals (Fig. 8E_5+5a and F_6) a left cuboid from an Infant individual (around $3<6$ months) and a right Adult cuneiform, respectively. Their medial plantar and lateral localizations could thus, in this case, also have been produced during phases of hide removal. 
Of great importance are the large carnivore remains that are accompanied by combustion. At Fumane, four remains from A5-A5+A6 (13\%) and four from A6 (21\%) show traces of thermal alteration. In four cases, a proximal epiphysis of a radius, a sesamoid, and two first phalanges were associated with cut-marks and localized combustion (Fig. 9A_4 and C_10, D_11; Fig. 10F). A single sesamoid without cut-marks was fully calcined (Fig. 9E_12). In general, these are primarily associated with small elements from appendicular extremities or particular portions of the limbs (radius), where the bone can be unprotected or insufficiently covered by important muscle mass. In at least two cases, there is an exceptional association of cut-marks, combustion, and human tooth marks. In fact, bitemarks compatible with human teeth (Saladiè et al., 2013) are recognized on a proximal epiphysis of a partially-combusted first phalanx, recovered within a combustion structure (USA5, SIII) (removal of part of one of the two proximal insertion tubercles), a lateral-distal diaphyseal flake from a tibia, and along the fractured edge of a proximal portion of a radius (Fig. 9 A_2+2a, 3+3a and B_7, C_8) in proximity to a marginal combustion. In general, all tooth marks are shallow and the pits are crescent-shaped. In the case of the radius, some cut-marks (Fig. 9A) are interpose (Fig. 9A_2I) or close (III-IV) to the tooth marks, which appear regular, equidistant (dental arch), and, towards the fracture margin, assume the characteristics of punctures with incomplete fractures, perimeter-contour, and flaking on the edges.

\section{FIGURES 8 AND 9 ABOUT HERE}

\subsection{Skeletal part representation}

The high number of remains of Ursus spelaeus, Ursus arctos and indeterminate bears, classified as Ursus sp. has permitted more detailed analyses to be proposed for the composition of the bear carcasses at Rio Secco Cave, but not Fumane Cave. Although a larger area was investigated at Fumane than Rio Secco, it did not return a number of remains sufficiently representative for calculations of $\%$ of Skeletal Survival Rate and Fragmentation Index (Tab. 4). Nevertheless, the 
distribution of the determined ursid remains across the two different levels of Fumane and the relative MNE (Tab. 4 and Fig. 3) shows that the cranial and limb regions are best represented. The trunk region is only represented by four ribs and a portion of vertebra.

At Rio Secco Cave, the remains, subdivided by anatomic element in craniocaudal order, show that the entire carcass is represented, with the exclusion of the coxal; the stilopodium (humerus/femur) and zeugopodium (radius-ulna/tibia-fibula) are well-represented in both stratigraphic units, in contrast with the low number of findings from the extremities of the limbs, like phalanges and sesamoids. The cranial remains (maxilla, hemimandible, and teeth) are certainly very well represented, by virtue of their resistance to mechanical and chemical stress (Tab. 4).

The MNE shows that the axial skeleton, with both vertebrae and ribs, is numerically the most abundant portion of the body. The survival coefficient (Skeletal Survival Rate), however, reveals a contrast with these results, showing that certain elements are clearly selectively underrepresented. Vertebrae and ribs, less resistant and thinner, have low values $(<8.9 \%)$ as compared with cranial remains (37.5-50.0\%), mandibles (37.5-40.6\%), and long bones like femurs (34.3-50\%), radii (9.3$41.6 \%)$, and tibias $(21.8-25 \%)$.

\section{TABLE 4 ABOUT HERE}

\subsection{Estimation age and minimum number of individuals}

The estimation of minimum number of individuals and age at death was difficult to ascertain due the fragmentation of the remains that mostly involved the long bones, ribs, cranium, or some teeth, which were frequently burnt and cracked into several fragments, and thus it was not always possible to advance comparisons between the different elements (Tab. 5 and Tab. $1 \mathrm{SI}$ ). In order not to distort the proportions of age groups present in the various units and in both cultural frequentations, estimations were also calculated for the remains generally determined as $U$. sp., considering only 
age or the sizes of animal not present in the two categories of determined taxa certain (U. arctos and U. spelaeus).

At Rio Secco Cave, the data indicate the presence in both levels of individuals of all ages, with a prevalence somewhat of adults and sub-adults (Tab. 5). In 5top+7 specifically, the MNI estimates at least 12 ursids (11 U. spelaeus; 1 U. arctos): U. Spelaeus- 2 Infants (around 1-12 months); 2 Young (2-3 years); 4 Adults of diverse ages, amongst which were two males (MNE=2 baculum); 3 Seniles ( $>20$ years); $U$. arctos -1 Generic Adult. Of the identified characteristics, no individual amongst the determined Ursus sp. remains (1 Infant and 1 Adult) increases the estimation in these levels. To date, in 5+8 an MNI of 16 ursids has been estimated (15 U. spelaeus; 1 U. arctos): U. Spelaeus- 1 Infant (4 months); 2 Young (12-20 months); 1 Young-Adult; 8 Adults of various ages and sizes amongst which is a probable female specimen and a male (MNE=1 baculum); 3 Seniles ( $>20$ years) were predominately identified by teeth and/or portions of mandibles with teeth in place; $U$. Arctos1 Generic Adult. Also in this level, of those individuals associated with the remains determined as U. sp. (1 Infant- 4 months; 1 Young-Adult, 1 Adult), none increase the MNI estimate.

At Fumane Cave, a combination of Infants, Young, and Adult individuals is noted amongst the levels, while Senile individuals are absent. In A5-A5+A6, an MNI of 5 ursids was estimated (1 $U$. spelaeus, 1 U. arctos, and 3 U. sp.): U. spelaeus- 1 Adult; U. arctos- 1 Adult; U. sp.- 1 Infant; 2 Young were not present amongst the age classes of the determined remains, which were taken into account for the MNI estimation; 1 Adult (>16 years) was not considered in the calculation. In A6, the MNI estimation included six ursids ( $3 U$. arctos and $3 U$. sp.): $U$. arctos- 1 Young-Adult, 2 Adults (two femurs of different sizes); 3 U. sp.- 2 Infants; 1 Young was not present in the age classes of determined remains and 1 Adult ( $>16$ years) was not considered in the calculation for the opposite reason.

Taking into consideration the partiality of the distribution area under investigation, it seems relevant to point out that: 1) despite the presence amongst the sites of infant and neonatal individuals, 
excavations have not revealed the presence of bear hibernation dens; 2) the presence/absence of older individuals could be a useful indicator of the typology of the differentiated use of the two cavities on the part of the two ursid species; in the case of Fumane Cave, this may indicate the result of "selection" by hunters.

\section{TAB.5 ABOUT HERE}

\subsection{Bear bone retouchers}

To date, five brown bear bone retouchers (Auguste, 2003; Valensi and Psathi, 2004) and seven cave bear bone retouchers, made from bone flakes from a femur, tibia and humerus (Abrams et al., 2014), can be accounted for in the Middle Palaeolithic of Europe. An additional six retouchers recovered in the two sites of this study can be added to this assemblage. At Rio Secco Cave, four retouchers (Tab. 6) were manufactured from rib diaphyses (2 Ursus sp. and 2 Ursus spelaeus), and present fractures attributable to the fresh state of the bone and are very homogenous in their dimensions and weight (Tab. 6 and Fig. 10A - D; L between 7 and $8.3 \mathrm{~cm}$; W between 1.4 e $1.7 \mathrm{~cm}$; and weight between 10.3 and 12.6gm). In general, the impressions are of linear type, rarely punctiform. On only one find (Fig. 10A_2), two cut-marks on the dorsal face (flaying or defleshing) were noted in association with the area utilized for retouching, which was localized ventrally (Fig. 10A_1), as in all the other cases (Fig. 10B, C and D). Only one retoucher present specific traces of combustion (Fig. 10F). At Fumane Cave, two retouchers are present, made from a first phalanx and an ulna from two brown bears of different ages (Tab. 6); both were recovered from A6 (Jéquier et al., 2012). The retoucher RIL 5805 was made from a left ulnar diaphysis medial from a Young/Adult individual, which is suggested by the muscular insertion surfaces that were still being formed. Fractures, cracks, and an impact notch (Fig. 10E_7), present medially, show the bone was fresh at the time of intentional fracturing. The linear-type impressions are present next to a long, fractured edge, positioned laterally to the element (Fig. 10E_6). The second brown bear retoucher 
(D853) is a phalanx from a Generic Adult individual, and presents a short, precise, and persistent series of striae on the plantar surface (Fig. 10F_8), attributable to one of the early stages of the hide removal from the extremities of the limbs. The distal epiphyses moreover show combustion- absent from one of the two condyles (Fig. 10F). The linear-type and punctiform impressions are localized on the dorsal proximal diaphyseal surfaces (Fig. 10F_9) and are characterized by their precision and the reduced number of impacts (around ten).

In general, at Fumane and Rio Secco some of the surfaces of ungulate bones retouchers have been scraped before being used, probably to remove meat and tendon residues or the periosteum (Jéquier et al., 2012; Peresani et al., 2014). This pattern is not observable on the ursid diaphyses retouchers from either site, which were utilized little following or during the butchery phase. At Fumane, punctiform and linear impressions, striations, and pits usually characterize functional areas on retouchers (Jéquier et al., 2012). Three different functional zones can be identified on some retouchers made from ungulate diaphyses; however, the totality of the ursid retouchers from both sites shows a single functional zone.

\section{FIGURE 10 ABOUT HERE}

\section{Discussion}

The data presented above demonstrate clear evidence for interactions between Neanderthals and cave and brown bears, which were targeted for the acquisition of fur, meat, bones, and possibly other materials that were considered plantigrade resources. However, as also demonstrated by the carnivore to herbivore ratios at both the sites, respectively 1:0.27 (Rio Secco) and 1:23 (Fumane), much of the variability between these caves can be contextualized in terms of the ways and the rhythms of bear exploitation. The survival coefficient describes a fragmentation rate that is not very high when compared with other Palaeolithic contexts where values are never less than 0.4. The 
smaller and more compact bones with values that tend toward an index of 1 could in reality be overestimated due to the low number of finds (carpals, tarsals, metapodials, and phalanges). The low representation of phalanges could be ascribed to their removal with animal fur (Fumane Cave), but also a differentiation of findings in the investigated area (Rio Secco Cave).

Like numerous caves across Europe, Rio Secco was almost exclusively used for bear hibernation, while Fumane shows evidence for intense and repeated Neanderthal settlement. Evidence from Rio Secco suggests targeted cave visits and the exploitation of bears by humans, which is comparable to three Mousterian sites in Europe that have been interpreted as evidence of active and directed hunting: Biache-Saint-Vaast in France (Auguste, 1992, 1995, 2003), Taubach in Germany (Bratlund, 1999; Gaudzinski et al., 2011), and Krapina in Croatia (Miracle, 2007). The bear bone accumulations are consistent: 7,013 bones at Biache (NISP with cut-marks 2,496; $U$. arctos and $U$. deningeri), 1,537 at Taubach (NISP with cut-marks 292; U. arctos), and 527 at Krapina (NISP with cut-marks 23; U. spelaeus, U. arctos, and $U$. sp.). These interpretations are based on the dominance of adults over young and senile individuals- a structure inverted with respect to that of a living population (adults in the minority, young and senior individuals the majority)- and traces of cuts of an anthropic origin, indicating diverse slaughtering activities (total extraction of hide or fur, disarticulation, and defleshing). At Biache, Auguste (1995) observes that young bear cubs are absent, while adults and sub-adults dominate and «a male/female ratio slightly biased in favor of the former indicates the predation of isolated individuals; this reflects the solitary behavior of ursids and rejects the killing of hibernated animals». He puts forward the hypothesis that the bear hunt occurred in the autumn, as it is the meat, fatty in this season, which was mostly used. The numerous cut-marks present on $10 \%$ of the ursid remains were mostly on the cranial and thoracic skeletal elements, and an analysis of age cohorts (Auguste, 2003) demonstrates that Biache is a kill site. The hypothesis is that Neanderthals took advantage of wetland areas and surrounding waterways to render vulnerable animals otherwise highly dangerous on dry ground (bear, aurochs, and rhinoceros) (Auguste, 1995). At Taubach, brown bears were exploited following their deaths 
(Bratlund, 1999): cut-marks are visible on a huge number of remains including maxillary and mandibular bones, vertebrae, long bones, pelvis, calcaneus, metapodial bones, and phalanges. At Krapina, the cut-marks are concentrated on the mandible and metapodials and may be related to the skinning of bear carcasses. At Caverna delle Fate, striae on a hyoid bone could attest to the extraction of the tongue by the Mousterians (Quilès, 2003), an operation that demands rapid execution following the plantigrade's death.

Rio Secco Cave is an isolated example in the Late Middle Palaeolithic contexts of northeast Italy although farther east in the Trieste karst there are many karstic cavities with abundant presence of cave bear remains that are associated with some ungulate and carnivore remains and lithic artifacts, including Grotta Pocala (Bartolomei, 1982), Caverna degli Orsi (Boschian, 1992, 2001, 2003; Boschian and Ota, 2002) and Riparo di Visogliano (Abbazzi et al., 2000; Cattani et al., 1991). However, detailed taphonomic analyses are still lacking and at the moment it is not possible exclude a priori any evidence for human-bear interactions. Sites across Italy have produced examples of alternating Neanderthal-large carnivore frequentations attested by handfuls of lithic artifacts in association with abundant bone remains, supposedly the result of natural deaths. This evidence can be characterized by the extreme conditions in which they are found, as in the case of Caverna Generosa, located at around 1,500m asl in the central Italian pre-Alps (Bona et al. 2007), and Grotta Lattaia, on Cetona Mount in southern Tuscany (Argenti and Mazza, 2006), the southern limit of the population range of the cave bear. At Grotta Lattaia, 107 Ursus spelaeus bones were found in association with Levallois tools dated to $48 \pm 4 \mathrm{ky}{ }^{14} \mathrm{C}$ BP.

In contrast, Fumane Cave (Fig. 2 and SI) is set in a region where variable evidence of bear and human frequentation has been produced, even if ephemeral for bears in some cases, from Fumane layer A9 (Romandini et al., 2014a), Riparo Tagliente (Thun-Hohenstein and Peretto, 2005), and Grotta della Ghiacciaia in the Lessini Mountains, from Grotta Maggiore di San Bernardino (Peresani, 1996) and Grotta de Nadale (Jéquier et al., 2015) in the Berici Hills, and ephemeral for humans from Grotta Paina (Gurioli et al., 2006), Grotta Col della Stria (Romandini, 2012), and 
Grotta del Broion (Peresani and Porraz, 2004) in the same area. Due to its geographic setting, Fumane holds a key position which may have facilitated human penetration into the mountain region. Each of these sites is located in different contexts, and their faunal assemblages indicate that the hunted ungulates- mostly red deer and roe deer with lesser incidence of chamois and ibex and limited exploitation of Bos/Bison, giant deer, elk and wild boar (Fiore et al., 2004; Thun-Hohenstein and Peretto, 2005) fit the ecological conditions around each site, showing shifts correlated with the most relevant climatic oscillations (Lopez-García et al., 2015).

In the atrial area of Fumane Cave, the extensive excavations of two Mousterian levels have yielded the ursid remains that have been analyzed here. These seem more to fit the treatment of carcasses within a human settlement equipped with hearths rather than bear hibernation. The total absence of atlas, axis, elements of the hyoid apparatus, scapula, and coxal remains, which could indirectly indicate a primary treatment of the carcass in a place other than the cave itself and the transport of limbs and crania, richest in meat. It cannot be excluded that the repeated Neanderthal frequentation of the cave contributed to the dispersion of the plantigrade elements toward the atrial area of the cavity. In contrast, at Rio Secco Cave, the bear carcasses, always recovered intact, are the result of capture and slaying late in their winter hibernation or approaching its beginning, as is demonstrated by the traces of anthropic modifications observed on Infant, Young and Adult individuals.

The presence of cubs at both sites further suggests that killing was also targeted to mothers (Rio Secco), although there is additional evidence of some males frequenting the cavity (os penis present at Rio Secco in both levels). Ethnographic comparisons suggest coherence in the interpretation of the archaeological data and attest to butchery and skinning nearly always occurring at the entrance to the den (cave/shelter), with particular care and attention paid to the fur removal (Binford, 2002).

According to the zooarchaeological bear assemblages from Rio Secco and Fumane, our data partially enable the procurement mode to be determined. This can be envisaged especially in the case of a hibernation site like Rio Secco, where the taphonomic background makes it almost impossible to distinguish between hunting and the exploitation of animals that died of natural 
causes. However, our data clearly demonstrate that the first manipulation of the bear carcass by humans was targeted at fur recovery, a task accomplishable only on animals that died very shortly before being skinned, and was probably planned to occur during denning time. This is also indicated by the activities aimed at the extraction of meat and marrow, the consumption of which is not strictly fixed in a timeframe, as it depends on taste preferences and food tolerances unknown today (Stiner et al., 1996). Given our certitude that the period of procurement has been established to be early spring at Fumane and early spring and/or preceding hibernation at Rio Secco, we suggest, following Stiner's ethnographic observations of Native American Indians (1994) and Pacher's (2000) and M nzel and Conard's (2004a, b) analyses of ethnographic data on bear hunting since the 17 th century, that the Neanderthal predation model was based on the opportunistic predation of bears during the first stages of hibernation and during winter, the favored season for hunting this plantigrade. It remains, however, problematic to imagine the possibilities and existing hunting techniques on the part of Neanderthal hunters in northern Italy, even knowing that the lithic assemblages are extremely lacking in stone points and that the prey species are among the largest represented of the carnivore order.

\section{Conclusion}

In general, the relation of Pleistocene trophic resources to vegetation zones rendered prey animals available only in accordance with seasonal rhythms, creating large geographic biozones and higher ranges of mobility (Kelly, 1995). The cycles and climate events furthermore diversely influenced the community structure depending on the regions considered. Interactions between Neanderthals and bears are inevitable in ecosystems in which two such similar species cohabitate, as they find or happen upon the remains of a carcass, near or around a cave/shelter (Blumenshine, 1986; Dominguez Rodrigo, 2000). This is evident at Rio Secco cave, where several indicators suggest that Neanderthals purposefully targeted this resource by moving across land devoid of lithics, at the 
edge of the alpine ridge and in an area peripheral to the alluvian plain to the south and the frequented regions to the west.

This is in contrast to Fumane cave, which was situated in a context proximal to widely available, productive lithic resources; as game, bears were secondary to ungulates. In this scenario, bears were a strategic or occasional resource for Neanderthals during their nomadic movements between the plain and the Alps.

\section{Acknowledgments}

Financial support to Rio Secco Research Project is provided by the Administration of the Clauzetto Municipality and the Friuli Venezia Giulia Region and a group of public institutions (Ecomuseo delle Dolomiti Friulane "Lis Aganis", BIM Tagliamento Consortium, Pordenone Province), Foundations (Fondazione CRUP) and private companies (Friulovest Banca). M. Peresani structured the research project and directed the fieldwork; M. Romandini coordinated the fieldwork. The Rio Secco project is also co-designed by the Neanderthal Museum (A. Pastoors \& G.C. Weniger) and the Universitat Rovira y Virgili at Tarragona (M. Vaquero). Research at Fumane is coordinated by the Ferrara University in the framework of a project supported by the Ministry of Culture - Veneto Archaeological Superintendency, public institutions (Lessinia Mountain Community - Regional Natural Park, Fumane Municipality, Veneto Region - Department for Cultural Heritage). This study has received funding from the European Research Council (ERC) under the European Union's

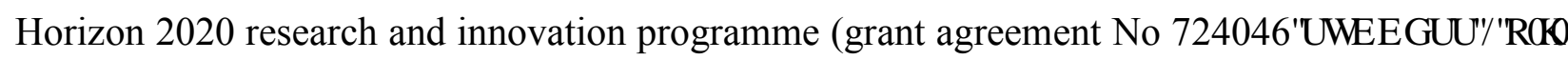

6MDQR[\%HD] ]D. We wish to thank Nicola Angeli of MUSE for technical assistance with the SEM. We are grateful to three anonymous reviewers for constructive suggestions, and to Kristen Heasley for translation from Italian and revision of the English text. Author contributions: M.P. and M.R. designed the research; M.R., G.T., N.N., A.T. analyzed data; M.R., G.T., N.N., A.T., M.P. wrote the paper. 


\section{References}

Abbazzi, L., Fanfani, E., Ferretti, M., Rook, L., Cattani, L., Masini, E., Mallegni, E., Negrino, F., Tozzi, C., 2000. New human remains of Archaic Homo sapiens and lower Palaeolithic industries from Visogliano (Duino Aurisina, Trieste, Italy). J. Archaeol. Sci. 27, 1173-1186.

Abrams, G., Bello, S.M., Di Modica, K., Pirson, S., Bonjean, D., 2014. When Neanderthals used cave bear (Ursus spelaeus) remains: Bone retouchers from unit 5 of Scladina Cave (Belgium). Quat. Int. 326-327, 274-287.

Alex, B., Boaretto, E. 2014. Radiocarbon chronology of Pešturina cave. In: Mihailović, D. (Ed.), Palaeolithic and Mesolithic research in the Central Balkans. Belgrade: Serbian Archaeological Society, pp. 39-47.

Andrews, P., Turner, A., 1992. Life and death of the Westbury bears. Ann. Zool. Fennici 28, 139149.

Argenti, P., Mazza, P.P.A., 2006. Mortality analysis of the Late Pleistocene bears from Grotta Lattaia, central Italy. J. Archaeol. Sci. 33, 1552-1558.

Arilla, M., Rosell, J., Blasco, R., Dominguez-Rodrigo, M., Pickering, T. R., 2014. The "Bear" Essential: Actualistic research on Ursus arctos arctos in the Spanish Pyrenees and its Implications for Paleontology and Archaeology. Plos One 9, 1-25.

Armand, D., Plassard, F., Prat, F., 2004. L'ours de Font-de-Gaume III et le problème de l'exploitation de l'ours des cavernes. Département de Rhône, Muséum, Lyon, Cahiers scientifiques, Hors série 2, 2004, 103-110.

Arribas, A., Palmqvist., P., 1999. On the ecological connection between sabre-tooths and hominids : faunal dispersal events in the lower Pleistocene and a review of the evidence for the first human arrival in Europe. J. Archaeol. Sci. 26 (5), 571-585.

Auguste, P., 1992. Étude archéozoologique des grands mammifères du site pléistocene moyen de Biache-Saint-Vaast (Pas-de-Calais, France): apports biostratigraphiques et palethnographiques. 
Anthropol. 96, 49-70.

Auguste, P., 1995. Chasse et charognage au paléolithique moyen: L'apport du gisement de BiacheSaint-Vaast (Pas-de-Calais). Bull. Soc. Prèhist. Fr. 92, 155-167.

Auguste, P., 2003. La chasse à l'ours au Paléolithique moyen: mythes, réalités et état de la question. In: Patou Mathis, M., Bocherens, H. (Eds.), Le rôle de l'environnement dans les comportements des chasseurs cueilleurs préhistoriques. BAR 1105, pp. 135-142.

Bächler, E., 1920-1921. Das Drachenloch ob Vättis im Taminatale. Jahrb. St. Gallische Nat.wiss. Ges.57

Bächler, E., 1923. Die Forschungsergebnisse im Drachenloch ob Vättis im Taminatale. Jahrb. St. Gallische Nat.wiss. Ges. 59.

Bächler, E., 1940. Das Alpine Paläolithikum der Schweiz. Monogr. Ur-u. Frühgesch. Schweiz 2, Basel.

Bernard-Guelle, S., 2000. Le gisement moustérien de plein air des Mourets (Villard-de-Lans. Isère) une nouvelle analyse de l'industrie. Préhist. Anthropol. méditerr., 1998-1999, Université de Provence, t. 7-8, p. 53-61

Bartolomei, G., 1982. Paleoecologia e Paleobiologia nel Carso di Trieste durante il Quaternario sulla base dei micromammiferi. Atti Mus. Civ. St. Nat. Trieste 34, 1-8.

Bertola S., Peresani M., Peretto C., Thun-Hohenstein U., 1999, Le site paléolithique moyen de la Grotta della Ghiacciaia (Préalpes de Vénétie, Italie du Nord). L’Anthr. 103, 377-390.

Binford, L.R., 1981. Bones, Ancient Men and Modern Myths. Academic Press, New York.

Binford, L.R., 2002. L'interaction ethnograpique homme-ours et le gisements europèens d'ours des caverns, in: Tillet, T., Binford, L.R. (Eds.), L'ours et l'Homme. Symposium d'Auberives - en Royans - Isère- France E.R.A.U.L. 100, pp.141-155.

Blackwell, B.A.B., Yu, E.S.K., Skinner, A.R., Turk, I., Blickstein, J.I.B., Turk, J., Yin, V.S.W., Lau, B., 2007. ESR dating at Divje Babe I, Slovenia in: Turk, I. (Ed.) Divje Babe I Upper Pleistocene Palaeolithic site in Slovenia. Part I, Geology and Palaeontology, pp. 151-157, Ljubljana. 
Blumenschine, R. J., 1986. Carcass Consumption Sequences and the Archaeological Distinction of Scavenging and Hunting. J. Hum. Evol. 15, 639-659.

Blumenschine, R.J., Selvaggio, M.M., 1988. Percussion marks on bone surfaces as a new diagnostic of hominid behavior. Nature 333, $763 \mathrm{e} 765$.

Bökönyi, S., 1970. A new method for the determination of the number of individuals in animal bone material. Am. J. Archaeol. 74, 291-292.

Bocherens, H., Bridault, A., Drucker, D.G., Hofreiter, M., Münzel, S.C., Stiller, M., van der Plicht, J., 2014. The last of its kind? Radiocarbon, ancient DNA and stable isotope evidence from a late cave bear (Ursus spelaeus ROSENMÜLLER, 1794) from Rochedane (France). Quat. Int. 339-340, 179-188.

Bona, F., Peresani, M., Tintori, A., 2007. Indices de Fréquentation humaine dans les Grottes à ours au Paléolitique moyen final. L'exemple de la Caverna Generosa dans les Préalps lombardes, Italie. Anthropol. 111, 290-320.

Bonifay, E., Vandermeersch, B., Couture, C., Panatonni, R., 2007. La sépulture néandertalienne du Regourdou (Montignac-sur-Vezère, Dordogne). Mercuès: Centre d'Etude et de Recherche sur les Lacs, Anciens lacs et Tourbières du Massif-Central.

Boschian, G., 1992. Una «Caverna ad Ursus» sul Carso triestino: la caverna degli orsi presso S. Dorlingo della Valle. Nota preliminare. Atti Soc. Tosc. Sci. Nat. Mem. 99, 151-159.

Boschian, G., 2001. Early Upper Pleistocene lithic industry from Caverna degli Orsi near San Dorligo della Valle (North eastern Italy). Atti Soc. Preist. Protost. Friuli-Venezia Giulia XII, 5565.

Boschian, G., 2003. Environment and hunters-gatherers mobility in the northern Adriatic region. Preist. Alp. 39, 91-102.

Boschian, G., Ota, D., 2002. 70.000 anni fa sul Monte Carso. Ossi, animali e uomini della Caverna degli Orsi. Riserva Naturale della Val Rosandra. Udine.

Bratlund, B., 1999. Taubach revisited. Jahrbuch des Römisch-Germanischen Zentralmuseums 
Mainz 46, 67-174.

Brugal, J.P., Diez-Lomana, C., Huguet, R., Michel, P., Rosell, J., 2001. Karstic cavities, natural bone accumulations and discrete human activities in the European paleolithic: some case studies, in: Haws, J.A., Hockett, B.S., Brugal, J.P. (Eds.), Paleolithic Zooarchaeology in Practice, B.A.R International series, Oxford 1564, pp. 1-12.

Brugal, J.P., Fosse, P., 2004. Carnivores et Hommes au Quaternarie en Europe de 1'Ouest. Rev. Paléobiol. 23, 575-595.

Buccheri, F., Bertè, D. F., Berruti, G.L.F., Cáceres, I., Volpe, L., Arzarello, M., 2016. Taphonomic analysis on fossil remains from the Ciota Ciara Cave (Piedmont, Italy) and new evidence of cave bear and wolf exploitation with simple quartz flakes by Neanderthal. Riv. Ita. Paléontol. Stratigr. $122,41-54$

Caloi, L., Palombo, M.R., Sardella, R., 1997. Preliminary considerations on the relationships between large carnivores and herbivores in the Plio-Pleistocene mammal faunas of Italy. Paleontol. Evol. 30-31, 235-246.

Camarós, E., Cueto, M., Teira, L., Münzel, S.C., Plassard, F., Arias, P., Rivals, F., 2017. Bears in the scene: Pleistocene complex interactions with implications concerning the study of Neanderthal behavior. Quat. Int. 1-10.

Capaldo, S.D., Blumenschine, R.J., 1994. A quantitative diagnosis of notches made by hammerstone percussion and carnivore gnawing on bovid long bones. Am. Antiq. 59, 724-748.

Cavanhié, N., 2009-2010. L'ours qui a vu l'homme? Étude archéozoologique et taphonomique du site paléolithique moyen de Regourdou (Montignac, Dordogne, France). Paléo 21, 39-64.

Cattani, L., Cremaschi, M., Ferraris, M. R., Mallegni, E., Masini, E, Scola, V., Tozzi, C., 1991. Le gisement du Pleistocene moyen de Visogliano (Trieste): restes humains, industries, environnement. Anthropol. 95 (1), 9-36.

Conard, N.J., 2011. The Demise of the Neanderthal Cultural Niche and the Beginning of the Upper Paleolithic in Southwestern Germany, in: Conard, N.J., Richter, J. (Eds.), Neanderthal Lifeways, 
Subsistence and Technology: One Hundred Fifty Years of Neanderthal Study. The Netherlands: Springer, pp. 223-240.

Costamagno, S., Théry-Parisot, I., Brugal, J.P., Guibert, R., 2005. Taphonomic consequences of the use of bones as fuel. Experimental data and archaeological applications, in: O’Connor, T. (Ed.), Biosphere to Lithosphere: New studies invertebrate taphonomy (Procedings of $9^{\text {th }}$ ICAZ conference, Durham 2002). Oxford: Oxbow Books, pp. 51-62.

Couturier, M.A.J., 1954. L'ours brun (Ursus arctos L.). Grenoble: Editions B. Arthaud. 904 pp.

Craighead, J.J., Varney, J.R., Craighead, F.C., 1974. A population analysis of the Yellowstone grizzly bears. Bull. For. Conserv. Exp. Sta. 40, 20 pp.

Cvetković, N.J., Dimitrijević, V.N., 2014. Cave bears (Carnivora, Ursidae) from the Middle and Late Pleistocene of Serbia: A revision. Quat. Int. 339-340, 197-208.

Diedrich C.G., 2012. Cave bear killers and scavengers from the last ice age of central Europe : feeding specializations in response to the absence of mammoth steppe fauna from mountainous regions. Quat. Int. 255, 59-78.

Dittrich, L., 1960. Milschgebissentwicklung und Zahnwechsel beim Braunba ren (Ursus arctos) und anderen Ursiden. Gegenbaurs Morphol. Jahrb. 101, 1-141.

Domínguez-Rodrigo, M., de Juana, S., Galán, A.B., Rodríguez, M., 2009. A new protocol to differentiate trampling marks from butchery cut marks. J. Archaeol. Sci. 36, 2643-2654.

Domínguez-Rodrigo, M., Piqueras, A., 2003. The use of tooth pits to identify carnivore taxa in tooth-marked archaeofaunas and their relevance to reconstruct hominid carcass processing behaviours. J. Archaeol. Sci. 30, 1385-1391.

Ehrenberg, K., 1958/59. Vom dermaligen Forschungsstand in der Höhle am Salzofen. Quärtar $10 / 11,237-251$.

Enloe, J.G., 2012. Neanderthals, Bears and Hyenas, oh my! Competition for Exclusive Use of Space. J. Taphon. 10(3-4), 185-195.

Fedele, F., 1968. Ricerche sui giacimenti quaternari del Monfenera. Studio sui macrommamiferi 
della caverna "Ciota Ciara" (scavi 1968). Riv. Antropol. 55, 247-269.

Fernández-Jalvo, Y., Andrews, P., 2011. When human chew bones. J. Hum. Evol. 60, 117-123.

Fiore, I., Gala, M., Tagliacozzo, A., 2004. Ecology and Subsistence Strategies in the Eastern Italian Alps during the Middle Palaeolithic. Int. J. Osteoarchaeol. 14, 273-286.

Fisher, W.J., 1995. Bone surface modifications in zooarchaeology. J. Archaeol. Method and Theory 2, 7-68.

Fosse, P., Morel, P., Brugal, J-P., 2002. Taphonomie et éthologie des ursidés pléistocènes, in: Tillet, T., Binford, L.R. (Eds.), L'ours et l'Homme. Symposium d'Auberives-en-Royans, Isère, France, pp.79-100.

Fosse, P., Cregut-Bonnoure, E., 2014. Ontogeny/growth of (sub) modern brown bear (Ursus arctos) skeleton : A guideline to appraise seasonality for cave bear (Ursus spelaeus) sites? Quat. Int. 339$340,275-288$.

Fourvel, J.B., Fosse, P., Brugal, J.P., Cregut-Bonnoure, E., Slimak, L., Tournepiche, J.F., 2014. Characterization of bear remains consumption by Pleistocene large carnivores (Felidae, Hyaenidae, Canidae). Quat. Int. 339-340, 232-244.

Gardeisen, A., 1994. Restes fauniques et stratégies de chasse dans le Pléistocène supèrieur de la grotte ouest du Portel (Ariège-France). PhD thesis, University Paul-Valéry, Montpellier III.

Gaudzinski-Windheuser, S., Roebroeks, W., 2011. On Neanderthal subsistence in last interglacial forested environments in Northern Europe, in: Conard, N.J., Richter, J. (Eds.), Neanderthal Lifeways, Subsistence and Technology: One Hundred Fifty Years of Neanderthal Study. The Netherlands: Springer, pp. 61-71.

Germonpré, M., Sablin, M.V., 2001. The Cave Bear (Ursus spelaeus) from Goyet, Belgium. The Bear den in Chamber B (bone horizon 4). Bull. Inst. Royal Sci. Nat. Belg. 71, 209-233.

Germonpré, M., Hämäläinen, R., 2007. Fossil Bear bones in the Belgian Upper Paleolithic: the possibility of a proto bear-ceremonialism. Arct. Anthropol. 44, 1-30.

Grayson, D.K., 1984. Quantitative Zooarchaeology: Topics in the Analysis of Archaeological 
Faunas. Academic Press, Orlando.

Gurioli, F., Parere, V., Sala, B., 2006. La fauna del wurmiano medio della Grotta di Paina (Colli Berici, Vicenza). Atti del V Convegno Nazionale di Archeozoologia, Rovereto 5, 27-32.

Hemmer, H., 2000. Out of Asia: a Paleoecological Scenario of man and his carnivorous competitors in the European lower Pleistocene, in: Lordkipanidze, D., Bar-Yosef, O., Otte, M. (Eds.), Early Humans at the gates of Europe), Early Humans at the Gates of Europe. Etudes et Recherches Archéoloques de 1’Université de Liège, Liège, pp. 99-106.

Higham, T., Brock, F., Peresani, M., Broglio, A., Wood, R., Douka, K., 2009. Problems with radiocarbon dating the Middle to Upper Palaeolithic transition in Italy. Quat. Sci. Rev. 28, 12571267.

Hille, P., Rabeder, G., 1986. Die Ramesch-Knochenhohle im Toten Gebirge. Mitt. Komm. Quartdrforsch. Osterr. Akad. Wiss. 6, 77.

Jakubiek, Z., 1993. Ursus arctos Linnaeus, 1758 - Braunbär, in: Stubbe, M., Krapp, F., Niethammer, J. (Eds.), Handbuch der Säugetiere Europas. Wiesbaden, 5 pp. 254-300.

Jéquier, J.P., 1975. Le Moustérien Alpin. Révision critique. Yverdon, Eburodunum.

Jéquier, C.A., Romandini, M., Peresani, M., 2012. Les retouchoirs en matières dures animales: une comparaison entre Moustérien final et Uluzzien. Palevol 11, 283-292.

Jéquier, C.A., Peresani, M., Romandini, M., Delpiano, D., Joannes-Boyau, R., Lembo, G., Livraghi, A., Lopez-Garcia, J.M., Obradovic, M., Nicosia, C., 2015. The De Nadale Cave, a single layered Quina Mousterian site in the North Italy. Quartär 62, 7-21.

Kelly, R.L., 1995. The Foraging Spectrum: Diversity in Hunter-Gatherer Lifeways. Smithsonian Institution Press, Washington D.C.

Kindler, L., 2012. Die Rolle von Raubtieren in der Einnischung und Subsistenz jungpleistozäner Neandertaler, Archäozoologie und Taphonomie der mittelpaläolithischen Fauna aus derBalver Höhle (Westfalen). Monographien des Römisch-Germanischen Zentralmuseums, Band 99, Mainz. 
Kitagawa, K., Krönneck, P., Conard, N.J., Münzel, S.C., 2012. Exploring cave use and exploitation among cave bears, carnivores and hominins in the Swabian Jura, Germany. J. Taphon 10, 439-461.

Klein, R.G., Cruz-Uribe, K., 1984. The Analysis of animal bones from archaeological sites. University of Chicago Press, Chicago.

Koby, F.E., 1941. Le "charriage a sec" des ossements dans le cavernes. Ecollogae Geologicae Hellvetiae 34, 319-320.

Koby, F.E., 1943. Les soi-disant instruments osseux du Paléolithique alpin et le charriage à sec des os d'ours des cavernes. Vehr. Naturf. Ges. Basel, 54, 59.

Koby, F.E., 1951. L’ours des cavernes et les Paléolitiques. Anthropol. 55, 304-308.

Koby, F.E., 1953. Les Paléolithiques ont-ils chassé l'ours des cavernes? Actes Soc. Jarassienne d'Emulation. 23, 1-48.

Kurtén, B., 1958. Life and death of the Pleistocene cave bear. Acta Zool. Fenn. 95, 1-59.

Kurtén, B., 1976. The cave bear story. Life and Death of a Vanished Animal, Columbia University Press, New Jork.

Landt, M. J., 2007. Tooth marks and human consumption: ethnoarchaeological mastication research among foragers of the Central African Republic. J. Archeol. Sci. 34, 1629-1640.

Le Tensorer, J.M., 1998. Le Paléolithique en Suisse, Grenoble, Édit. Jérôme Milion, 499 p.

López-García, J.M., dalla Valle, C., Cremaschi, M., Peresani, M., 2015. Reconstruction of the Neanderthal and Modern Human landscape and climate from the Fumane cave sequence (Verona, Italy) using small mammal assemblages. Quat. Sci. Rev. 128, 1-13.

Majkić, A., d'Errico, F, Milošević, S., Mihailović, D., Dimitrijević, V. 2017. Sequential Incisions on a Cave Bear Bone from the Middle Paleolithic of Pešturina Cave, Serbia. J. Archaeol. Method and theory, DOI 10.1007/s 10816-017-9331-5.

Miracle, P.T., 2007. The Krapina Paleolithic Site: Zooarchaeology, taphonomy and catalog of the faunal remains. Croatian Natural History Museum, Zagreb. 
Münzel, S.C., 1997. Seasonal activities of human and non-human inhabitants of the Geißenklöosterle-cave near Blaubeuren, Alb-Danube District. Anthropozool. 25/26, 355-361.

Münzel, S.C., Conard, N.J., 2004a. Cave bear hunting in the Hohle Fels, a cave site in the Ach valley, Swabian Jura. Rev. de Paléobiol. 23, 877-885.

Münzel, S.C., Conard, N.J., 2004b. Change and Continuity in Subsistence during the Middle and Upper Paleolithic in the Ach valley of Swabia (SW-Germany). Int. J. Osteoarchaeol. 14, 1-15.

Münzel, S.C., Stiller, M., Hofreiter, M., Mittnik, A., Conard, N.J., Bocherens, H., 2011. Pleistocene bears in the Swabian Jura (Germany): genetic replacement, ecological displacement, extinctions and survival, in: Bocherens, H., Pacher, M. (Eds.), Late Quaternary Mammal Ecology: Insight from New Approaches. Special Volume of Quat. Int. 245, pp. 225-237.

Nelson, D.E., Ku, T.L., 1997. Radiocarbon dating of bone and charcoal from Divje babe I cave, in: Turk, I. (Ed.), Mousterian "bone flute" and other finds from Divje babe I cave site in Slovenia 2. Opera Instituti Archaeologici Sloveniae, pp. 51-65, Ljubljana.

Pacher, M., 2000. Taphonomische Untersuchungen der Höhlenbären-Fundstellen in der Schawabenreith-Höhle bei Lunz am See (Niederösterreich). Beitr. Paläontol. 25, 11-85.

Pacher, M., 2003. Upper Pleistocene cave assemblages at alpine sites in Austria and adjacent regions. Preist. Alp. 39, 115-127.

Peresani, M., 1996. Sistemi tecnici di produzione litica nel Musteriano d'Italia. Studio tecnologico degli insiemi litici delle unità VI e II della Grotta di San Bernardino (Colli Berici, Veneto). Riv. Sci. Pr. XLVII, 79-167.

Peresani, M., 2012. Fifty thousand years of flint knapping and tool shaping across the Mousterian and Uluzzian sequence of Fumane cave, in: Carbonnell, E., Gema, M., Vaquero, M. (Eds.), The Neanderthal Home: Spatial and Social Behaviours. Quat. Int. 247, pp. 125-150.

Peresani, M., Porraz, G., 2004. Ré-interprétation et mise en valeur des niveaux moustériens de la Grotte du Broion (Monti Berici, Vénétie). Etude techno-économique des industries lithiques. Riv. Sci. Pr. LIV: 181-247 
Peresani, M., Cremaschi, M., Ferraro, F., Falguères, C., Bahain, J.J., Gruppioni, G., Sibilia, E., Quarta, G., Calcagnile, L., Dolo, J.M., 2008. Age of the final Middle Palaeolithic and Uluzzian levels at Fumane Cave, northern Italy, using 14C, ESR, 234U/230Th and thermoluminescence methods. J. Archaeol. Sci. 35, 2986-2996.

Peresani, M., Chrzavzez, J., Danti, A., de March, M., Duches, R., Gurioli, F., Muratori, S., Romandini, M., Trombino, L., Tagliacozzo, A., 2011a. Fire-places, frequentations and the environmental setting of the final Mousterian at Grotta di Fumane, a report from the 2006-2008 research. Quartär 58, 131-151.

Peresani, M., Fiore, I., Gala, M., Romandini, M., Tagliacozzo, A., 2011b. Late Neandertals and the intentional removal of feathers as evidenced from bird bone taphonomy at Fumane cave 44ky BP, Italy. PNAS 108, 3888-3893

Peresani, M., Vanhaeren, M., Quaggiotto, E., Queffelec, A., d'Errico, F., 2013. An ochered fossil marine shell from the Mousterian of Fumane Cave, Italy. PLosOne, 8(7), e68572.

Peresani, M., Romandini, M., Duches, R., Jéquier, C., Nannini, N., Pastors, A., Picin, A., Schmidt, I., Vaquero, M., Weniger, G. C., 2014. New evidence for the Neanderthal demise and earliest Gravettian occurrences at Rio Secco Cave, Italy. J. F. Archaeol. 39, 401-416.

Peresani, M., Cristiani, E., Romandini, M., 2016. The Uluzzian technology of Grotta di Fumane and its implication for reconstructing cultural dynamics in the Middle - Upper Palaeolithic transition of Western Eurasia. J. Hum. Evo. 91, 36-56.

Petram, W., Knauer, F., Kaczensky, P., 2004. Human influence on the choice of winter dens by European brown bears in Slovenia. Biol.Conserv. 119, 129-136.

Pickering, T.R., Egeland, C.P., 2006. Experimental patterns of hammerstone percussion damage on bones: Implications for inferences of carcass processing by humans. J. Archaeol. Sci. 33, 459-469.

Pickering, T. R., Domínguez-Rodrigo, M., Heaton, J. L., Yravedra, J., Barba, R., Bunn, H. T., Musiba, C., Baquedano, E. Diez-Martín, F., Mabulla, A., Brain, C.K., 2013. Taphonomy of ungulate ribs and the consumption of meat and bone by 1.2-million-year-old hominins at Olduvai 
Gorge, Tanzania. J. Archeol. Sci. 40, 1295-1309

Potts, R., Shipman, P., 1981. Cutmarks made by stone tools on bones from Olduvai Gorge, Tanzania. Nature 291, 577-580.

Quilès, J., 2003. Les Ursidae du Pléistocène moyen et supérieur en Midi méditerranéen: Apports paléontologiques, biochronologiques et archéozoologiques. $\mathrm{PhD}$ thesis, National Museum of Natural History, Paris.

Quilès, J., 2004. Tanières d'ours des cavernes (Carnivora, Ursidae) du pourtour Méditerranéen: étude taphonomique et paléobiologique de huit assemblages du Pléistocène supérieur. Paleo16, 171-192.

Romandini, M., 2012. Analisi archeozoologica, tafonomica, paleontologica e spaziale dei livelli Uluzziani e tardo-Musteriani della Grotta di Fumane (VR). Variazioni e continuità strategicocomportamentali umane in Italia Nord-Orientale: i casi di Grotta del Col della Stria (VI) e Grotta del Rio Secco (Pn) (PhD Thesis). University of Ferrara.

Romandini, M., Nannini, N., Tagliacozzo, A., Peresani, M., 2013. Hunting bear during the Late Mousterian. Evidence from the North of Italy. ESHE Proceedings, 3rd Meeting, 189.

Romandini M., Nannini N., Tagliacozzo A., Peresani M., 2014a. The ungulate assemblage from layer A9 at Grotta di Fumane, Italy: a zooarchaeological contribution to the reconstruction of Neanderthal ecology. Quat. Int. 337, 11-27.

Romandini, M., Peresani, M., Laroulandie, V., Metz, L., Pastoors, A., Vaquero, M., Slimak, L., 2014b. Convergent evidence of eagle talons used by Late Neanderthals in Europe: a further assessment on symbolism. PLoS ONE 9(7), e101278.

Saladié, P., Rodríguez-Hidalgo, A., Díez, C., Martín-Rodríguez, P., Carbonell, E., 2013. Range of bone modifications by human chewing. J. Archaeol. Sci. 40, 380-397.

Selvaggio, M.M., Wilder, J., 2001. Identifying the involvement of multiple carnivore taxa with archaeological bone assemblages. J. Archaeol. Sci. 28, 465-470.

Shipman, P., 1981. Life History a Fossil. An Introduction to Taphonomy and Paleoecology. Harvard 
University Press, Harvard.

Shipman, P., Rose, J., 1984. Cutmark mimics on modern fossil bovid bones. Curr. Anthropol. 25, 116-177.

Stiner, M.C., 1994. Honor among Thieves. A Zooarchaeology Study of Neandertal Ecology. Princeton, New Jersey: Princeton University Press.

Stiner, M.C., Kuhn, S.L., Weiner, S., Bar-Yosef, O., 1995. Differential burning, recrystallization and fragmentation of archaeological bone. J. Archaeol. Sci. 22, 223-237.

Stiner, M. C., Arsebük, G., Howell, F. C., 1996. Cave bears and Paleolithic artefacts in Yarimburgaz Cave, Turkey: dissecting a palimpsest. Geoarchaeol. 11, 279-327.

Stiner, M., 1998. Mortality analysis of Pleistocene bears and its paleoanthropological relevance. J. Hum. Evol. 34, 303-326.

Tagliacozzo, A., Romandini, M., Fiore, I., Gala, M., Peresani, M., 2013. Animal exploitation strategies during the Uluzzian at Grotta di Fumane (Verona), in: Clark, J.L., Speth J.D. (Eds.), Zooarchaeology and Modern Human Origins: Human Hunting Behavior during the Later Pleistocene. Vertebrate Paleobiology and Paleoanthropology Series, Springer Science, New York, pp. 129-150.

Talamo, S., Peresani, M., Romandini, M., Duches, R., Jéquier, C., Nannini, N., Pastors, A., Picin, A., Vaquero, M., Weninger, G. C., Hublin, J. J., 2014. Detecting human presence at the border of the northeastern Italian Pre-Alps. 14C dating at Rio Secco Cave as expression of the first Gravettian and the late Mousterian in the northern Adriatic region. Plos ONE 9(4), e95376.

Thun-Hohenstein, U., Peretto, C., 2005. The exploitation of the faunal remains in the Mousterian levels at Riparo Tagliente (Verona, Italy), in: Molines, N., Moncel, M.H., Monnier J.L. (Eds.), Données recents sur les modalités de peuplement et sur le cadre chronostratigraphique. Geologique et paleogeographique des industries du Paléolithique inferieur et moyen en Europe. B.A.R. International Series, Oxford, 1364, pp. 261-268. 
Tillet, T., 1997. Les grottes a ours et occupations neanthertalienses dans les alpes, in: L'Homme et l'ours / Man and bear: Colloque international / International Meeting, Auberives en Royans Isere du 4 au 6 Novembre 1997 Tillet, T., Binford, L., dir Grenoble. Groupe Interuniversitaire de Recherche sur les peuplements et paleomileux alpins GIRPPA.

Tillet, T., Bernard-Guelle, S., 1998. Behaviour patterns, strategies and seasonality in the mousterian site of preletang (Vercors): The mousterian in Alps. Proceedings of the XIII Int. Congr. Prehist. Protohist. Sciences 6, 319-326.

Torres, T., 1976. Comparación entre algunos aspectos ecológicos de dos poblaciones de oso de las cavernas. Actas IV Congreso Nac. Espeleologia Marbella, 104-125.

Torres, T., 1984. Ursidos del Pleistoceno-Holoceno de la Península Ibérica. Ph.D. Dissertation, Politechnical University, Madrid.

Torres, T. J. 1988. Osos (Mammalia, Carnviora, Ursidae) del Pleistoceno de la Península Ibérica. Publicaciones especiales de boletín geologica y minero.

Torres, T., Ortiz, J.E., Cobo, R., de Hoz, P., García-Redondo, A., Grün, R., 2007. Hominid exploitation of the environment and cave bear populations. The case of Ursus spelaeus Rosenmüller-Heinroth in Amutxate cave (Aralar, Navarra-Spain). J. Hum. Evol. 52, 1-15.

Turk, I., (Ed.) 1997. Mousterian "Bone Flute" and Other Finds from Divje Babe I Cave Site in Slovenia, vol. 2. Opera Instituti Archaeologici Sloveniae, Ljubljana.

Turk, I., (Ed.) 2014. Cave bear: prey of Neanderthal hunters or animal of special importance? vol. 2. Opera Instituti Archaeologici Sloveniae, Ljubljana.

Turner, A., 1992. Large carnivores and earliest European hominids: changing determinants of resource availability during the lower and middle Pleistocene. J. Hum. Evol. 22, 109-126.

Turner, A., 1994. Evolution and dispersion of large Mammals in Europe during the time span of Homo erectus. Cour. Forsch. Senckenberg 171, 241-247. 
Turner, A., 1995. Regional variations in lower and middle Pleistocene larger mammal faunas of Europe: an Iberian perspective. Human evolution in Europe and the Atapuerca evidence. Proceedings of a Workshop vol. 1, 57-73, Valladodid.

Valensi, P., Psathi, E., 2004. Faunal Exploitation during the Middle Palaeolithic in South-eastern France and North-western Italy. Int. J. Osteoarchaeol. 14, 256-272.

Villa, P., Mahieu, È., 1991. Breakage patterns of human long bones. J. Hum. Evol. 21, 27-48.

Viranta, S., Grandal d'Anglade, A., 2012. Late Pleistocene large mammal paleocommunities: a comparative study between localities with brown bear (Ursus arctos), cave bear (U. spelaeus) and Mousterian lithic assemblage. J. Taphon. 10 (3e4), 265-276.

Watts, P. D., Jonkel, C., 1988. Energetic cost of winter dormancy in grizzly bear. J. Wildl. Manag. $52,654-656$.

Weinstock, J., 2009. Epiphyseal fusion in brown bears: a population study of grizzlies (Ursus arctos horribilis) from Montana and Wyoming. Int. J. Osteoarchaeol. 19, 416-423.

Wojtal, P., 2007. Zooarchaeological Studies of the Late Pleistocene Sites in Poland (Kraków).

Wojtal, P., Wilczyński, J., Nadachowski, A., Münzel, S.C., 2015. Gravettian hunting and exploitation of bears in Central Europe. Quat. Int. 359-360, 58-71. 


\section{Tables and figures captions}

Table 1: Middle Palaeolithic sites in Europe with evidence of bear exploitation; dates with (REF) references and REF of $M P$ Middle Palaeolithic/Mousterian $+C M$ cut-marked bear bones. B07Blackwell et al. (2007); N97-Nelson and Ku (1997); B07-Bonifay et al. (2007); S94-Stiner (1994); P03-Pacher (2003); P14-Peresani et al. (2014); T14-Talamo et al. (2014); H09-Higham et al. (2009); A14-Alex and Boaretto (2014); C11-Conard (2011); A92-95-03-Auguste (1992-19952003); T14-97 Turk (2014-1997); M07-Miracle (2007); A14-Abramas et al. (2014); K12-Kindler (2012); G11-Gaudzinski-Windheuser and Roebroeks (2011); B99-Bratlund (1999); V04-Valenci and Psathi (2004); C09-10-Cavanhié (2009-2010); B16-Buccheri et al. (2016 ); E58/59- Ehrenberg (1958/1959); Q03-05-Quilès (2003-2005); A04-Armand et al. (2004); P14-Peresani et al. (2014); R13-14-Romandini et al. (2013, 2014b); P11-Peresani et al. (2011a); M17-Majkić et al. (2017); M11-Münzel et al. (2011); M04b-M04a-Münzel and Conard (2004a-b); M97-Münzel (1997); K12Kitagawa et al. (2012); W15-Wojtal et al. (2015); G01-Germonpré and Sablin (2001); G07Germonpré and Hämäläinen (2007); W07-Wojtal (2007).

Table 2: Mammal NISP and NISP\% for the late Mousterian layers at Rio Secco Cave (RS) and Fumane Cave (FC). The countings are based on bones and teeth.

Table 3: Number of anatomical elements of Ursidae with anthropogenic modifications and carnivore marks; $C M$ cut-marks, $P M$ percussion marks, $C M+P M$ cut-marks + percussion marks, $P e$ peeling, $B M$ butchery marks, $\% B M, R$ retoucher, $T M$ tooth marks, $B$ burned, $G M$ gnaw marks.

Table 4: Anatomical elements of Ursidae (Ursus arctos, Ursus spelaeus, and Ursus sp.); NISP, $M N E, N E E, \%$ skeletal survival rate, and breakage index.

Table 5: NISP and MNI divided by age of Ursus arctos, Ursus spelaeus, and Ursus sp. in the late Mousterian layers at Rio Secco Cave (RS) and Fumane Cave (FC). 
Table 6: Identification number, site, layer, anatomical portion, taphonomy, and measurement of the bear bones retouchers; $F f r B$ fresh bone fracture, $C M$ cut-marks, $P M$ percussion marks, $B$ burned, $L$ length, $W i$ width, $T$ thickness, $W e$ weight.

Table S1: Supplementary information: Anatomical elements of Ursidae (Ursus arctos, Ursus spelaeus, and Ursus sp.); NISP and MNI.

Figure 1: Middle Palaeolithic European sites with evidence of bear exploitation cited in this study. BV (Biache-Saint-Vaast), KR (Krapina), DB (Divje Babe), SC (Scladina Cave), BC (Balve Cave), TA (Taubach), CF (Caverna delle Fate), AM (Arma delle Manie), MA (Madonna dell'Arma), CS (Crvena Stijena); RG (Regourdou), CC (Ciota Ciara Cave), SA (Sant'Agostino), BA (Badalucco), SH (Salzofenhöhle), RS (Rio Secco Cave), FC (Fumane Cave), PC (Pešturina Cave), GK (Geißenklösterle), HF (Hohle Fels), GC (Goyet), NC (Nietoperzowa Cave).

Figure 2: Panoramic views, schematic plan, and location of stratigraphic profiles (in red) of Fumane Cave (A-A1-A2) and Rio Secco Cave (B-B1-B2), with Mousterian layers indicated.

Figure 3: Distribution of butchery marks on the Ursidae skeletal elements (Ursus spelaeus, Ursus arctos, and Ursus sp.) from Rio Secco Cave (A-B) and Fumane Cave (C-D).

Figure 4: Rio Secco Cave levels 5top+7, localization and details of the cut marks: A) right ulna of U. spelaeus with traces on the proximal end (1-close-up of striae); B) right radius of $U$. spelaeus with traces on the proximal end (2); C) right ulna of U. arctos with traces on proximal epiphysis (34); D) right radius of infant (8-12 months) $U$. sp. with traces on proximal end (5); E) right radius of U. spelaeus with traces on diaphysis (6) and burning (red arrow); F) left femur of U. spelaeus with percussion marks (white arrow); G) right tibia of $U$. spelaeus with traces on diaphysis (7); H) left tibia of $U$. spelaeus with traces on diaphysis (8); I) first phalanx of U. spelaeus with traces (9) and localization and detail of burned portion (red arrow - 10).

Figure 5: Rio Secco Cave levels 5top+7, localization and details of bear ribs (U. sp. A-B; $U$. 
spelaeus C-D) with cut-marks (1-2-3), peeling (4-6-7), and burned portion (5 and red arrow), oriented according to figures A-B-C-D.

Figure 6: Rio Secco Cave levels 5+8, localization and details of cut-marks: A) right hemimandible of $U$. spelaeus with traces on condylar portion acquired by SEM (1-1a) and burning (red arrow); B) rib of $U$. sp. with traces (2); C) rib of $U$. sp. with different traces (3-4); D) left ulna of U. spelaeus with traces on distal end acquired by $\operatorname{SEM}(7-7 \mathrm{a})$; E) right radius of $U$. sp. with traces on diaphysis (5); F) thoracic vertebra of $U$. sp. with traces acquired by SEM (6-6a); G) left femur of $U$. sp. with traces on diaphysis (8) and percussion marks (white arrow) and percussion cone in connection; $\mathrm{H}$ ) left fibula of generic young $U$. sp. with traces on diaphysis (9); I) left tibia of $U$. spelaeus with traces on distal diaphysis (10); L) second phalanx of U. spelaeus with traces of burning (red arrow).

Figure 7: Rio Secco cave (level 8), right scapula of U. spelaeus No. RIL. 226, different views: (A) lateral view; (B) medial view. The numbers 1-5 indicate the localization and close-ups of the traces oriented according to figures $\mathrm{A}$ and $\mathrm{B}$. The red arrow indicate localization of burned portion and picture detail (6).

Figure 8: Fumane Cave (A5-A6), localization and details of anthropic traces: A) right radius of $U$. sp. with traces on proximal end (1-1a); B) left fibula of $U$. arctos with traces on diaphysis (2-3 and 3a acquired by SEM); C) left femur of $U$. arctos with scrapers on diaphysis (4); D) right femur of $U$. arctos with percussion marks (white arrow); E) left cuboid of infant ( $3<6$ months) $U$. sp, with traces (5 and 5a acquired by SEM); F) right cuneiform of $U$. arctos with traces (6); G) third right metapodial of $\mathrm{U}$. arctos with traces (7); H) sesamoid of $U$. sp with traces (8).

Figure 9: Fumane Cave (A5-A6), localization and details of anthropic traces: A) right radius of $U$. sp. with traces on diaphysis (1-2_III-IV and 5), tooth marks (grey arrows - 2 and 3), details of tooth marks acquired by SEM (2a-3a), localization and detail of burned portion (red arrow - 4); B) tibia of $U$. sp. with traces on diaphysis (6) and tooth marks (grey arrows - 7); C) first phalanx of $U$. arctos with traces (9), tooth marks (grey arrows - 8), localization and detail of burned portion (red 
arrows - 10); D) sesamoid of $U$. sp. with cut marks and detail of burned (11); E) sesamoid of $U$. sp. localization and details of calcination (red arrow -12).

Figure 10: Bear bone retouchers from Rio Secco (A-D) and Fumane Cave (E and F): A) rib of $U$. spelaeus with linear marks produced during knapping on ventral surface (1) and cut-marks on dorsal surface (2); B) rib of U. spelaeus with pits produced during knapping (3); C-D) ribs of $U$. sp. with linear marks (4 and 5); E) left ulna of young/adult $U$. arctos with linear marks (6) and impact point on medial surface (7); F) first phalanx of $U$. arctos with cut-marks on plantar diaphysis (8 acquired by SEM) and pits produced during knapping on dorsal surface (9). The red arrow indicates the localization of burned portion; the white arrow indicates percussion marks. 


\begin{tabular}{|c|c|c|}
\hline $\begin{array}{l}\text { Sites } \\
\text { Layer }\end{array}$ & $\begin{array}{c}\text { Date }-(\text { REF }) \\
\text { Kyr Cal BP or MIS }\end{array}$ & $\begin{array}{c}\text { REF } \\
\text { (MP/Mousterian } \\
+ \text { CM on Bears) } \\
\end{array}$ \\
\hline $\begin{array}{l}\text { Biache-Saint-Vaast (BV) } \\
\text { IIa-II } \alpha \text {-II base }\end{array}$ & $250-200$ & A92-A95-A03 \\
\hline $\begin{array}{l}\text { Krapina }(\mathrm{KR}) \\
5-6\end{array}$ & $130-100$ & M07 \\
\hline $\begin{array}{l}\text { Divje Babe (DB) } \\
\text { A, A/B, B, C, D-1, D-2, E-1, } \\
\text { E-2 }\end{array}$ & 115-30 (B07-N97) & T14-T97 \\
\hline $\begin{array}{l}\text { Scladina Cave (SC) } \\
\text { Unit } 5\end{array}$ & MIS 5d-5b & A14 \\
\hline Balve Cave (BC) & & K12 \\
\hline Taubach (TA) & MIS 5 & G11-B99 \\
\hline Caverna delle Fate (CF) & OIS 5 to 3 & V04 \\
\hline Arma delle Manie (AM) & OIS 5 to 3 & V04 \\
\hline Madonna dell'Arma (MA) & OIS 5 & V04 \\
\hline Crvena Stijana (CS) & MIS 3 & $\begin{array}{l}\text { E. Morin (personal } \\
\text { communication) }\end{array}$ \\
\hline Regourdou (RG) & $90-60(\mathrm{~B} 07)$ & $\mathrm{C} 09-10$ \\
\hline Ciota Ciara Cave (CC) & MIS 5 & B16 \\
\hline $\begin{array}{l}\text { Sant'Agostino (SA) } \\
\text { S1 }\end{array}$ & 55-43 (S94) & S94 \\
\hline Badalucco (BA) & $\sim 50$ & Q03-Q04 \\
\hline Salzofenhöhle (SH) & $>49$ (P03) & E58/59 \\
\hline $\begin{array}{l}\text { Rio Secco Cave (RS) } \\
5 \text { top }+7 \text { and } 5+8\end{array}$ & 49-42 (P14-T14) & P14-R13-R14-this article \\
\hline $\begin{array}{l}\text { Fumane Cave (FC) } \\
\text { A5-A5+A6 and A6 }\end{array}$ & 44-42 (H09) & P11-this article \\
\hline $\begin{array}{l}\text { Pešturina Cave (PC) } \\
4\end{array}$ & 44-43 (A14) & M17 \\
\hline $\begin{array}{l}\text { Geißenklösterle (GK) } \\
\text { IV-VIII }\end{array}$ & $43(\mathrm{C} 11)$ & M11-M04b-M97-K12 \\
\hline Hohle Fels (HF) & $40-33(\mathrm{C} 11)$ & M11-M04a-W15 \\
\hline $\begin{array}{l}\text { Goyet (GC) } \\
\text { B4 }\end{array}$ & $40-41$ & G01-G07 \\
\hline Nietoperzowa cave (NC) & & W07-W15 \\
\hline
\end{tabular}




\begin{tabular}{|c|c|c|c|c|c|c|c|c|}
\hline \multirow[b]{2}{*}{ Taxa } & \multicolumn{2}{|c|}{$R S-$ levels 5 top +7} & \multicolumn{2}{|c|}{$R S-$ levels $5+8$} & \multicolumn{2}{|c|}{$\begin{array}{c}F C-\text { levels A5- } \\
A 5+A 6\end{array}$} & \multicolumn{2}{|c|}{ FC-level A6 } \\
\hline & NISP & NISP \% & NISP & NISP \% & NISP & NISP \% & NISP & NISP \% \\
\hline Lepus sp. & & & 1 & 0.2 & 1 & 0.1 & & \\
\hline Marmota marmota & 43 & 11.4 & 257 & 44.1 & & & 1 & 0.1 \\
\hline Erinaceus europaeus & & & 1 & 0.2 & & & & \\
\hline Total Lagomorpha and Rodentia & 43 & 11.4 & 259 & 44.5 & 1 & 0.1 & 1 & 0.1 \\
\hline Canis lupus & & & 3 & 0.5 & 4 & 0.5 & 7 & 0.3 \\
\hline Vulpes vulpes & 1 & 0.3 & 3 & 0.5 & 26 & 3.1 & 20 & 0.8 \\
\hline Vulpes/Alopex & & & & & 3 & 0.4 & & \\
\hline Ursus arctos & 6 & 1.6 & 1 & 0.2 & 4 & 0.5 & 10 & 0.5 \\
\hline Ursus spelaeus & 148 & 39.3 & 157 & 27 & 2 & 0.2 & & \\
\hline Ursus sp. & 66 & 17.5 & 64 & 11 & 13 & 1.5 & 21 & 0.9 \\
\hline Martes martes & & & 3 & 0.5 & & & & \\
\hline Martes sp. & 1 & 0.3 & & & & & & \\
\hline Meles meles & & & 2 & 0.3 & & & & \\
\hline Mustela erminia & & & 4 & 0.7 & & & & \\
\hline Mustela nivalis & & & & & & & 1 & 0.1 \\
\hline Mustelidae & & & 2 & 0.3 & & & & \\
\hline Carnivora indet. & 27 & 7.8 & 25 & 4.3 & 2 & 0.2 & 14 & 0.6 \\
\hline Total Carnivora & 249 & 66.2 & 262 & 45.3 & 54 & 6.4 & 73 & 3.2 \\
\hline Sus scrofa & 1 & 0.3 & 2 & 0.3 & & & 2 & 0.1 \\
\hline Megaloceros giganteus & 14 & 3.7 & 5 & 0.9 & 10 & 1.2 & 28 & 1.2 \\
\hline Alces alces & 5 & 1.3 & 2 & 0.3 & 1 & 0.1 & 4 & 0.2 \\
\hline Cervus elaphus & 6 & 1.6 & 7 & 1.2 & 297 & 35.5 & 1095 & 48 \\
\hline Capreolus capreolus & & & 1 & 0.2 & 48 & 5.7 & 182 & 8 \\
\hline Cervidae indet. & 19 & 5.1 & 6 & 1 & 39 & 4.6 & 128 & 5.6 \\
\hline Bison priscus & 2 & 0.5 & 1 & 0.2 & & & 2 & 0.1 \\
\hline Bos/Bison & 8 & 2.1 & 10 & 1.7 & 10 & 1.2 & 13 & 0.6 \\
\hline Capra ibex & 2 & 0.5 & 5 & 0.9 & 30 & 3.6 & 54 & 2.4 \\
\hline Rupicapra rupicapra & & & 3 & 0.5 & 32 & 3.9 & 55 & 2.4 \\
\hline Caprinae indet. & 1 & 0.3 & & & 12 & 1.4 & 7 & 0.3 \\
\hline Ungulata indet. & 26 & 6.9 & 17 & 2.9 & 302 & 36.2 & 630 & 27.8 \\
\hline Total Ungulata & 84 & 22.3 & 59 & 10.2 & 781 & 93.4 & 2200 & 96.7 \\
\hline Total NISP & 376 & 100 & 582 & 100 & 836 & 100 & 2274 & 100 \\
\hline \multicolumn{9}{|l|}{ Indeterminate } \\
\hline Mammals small size & 1 & & 20 & & 10 & & 7 & \\
\hline Mammals medium-small size & 1 & & 17 & & 7 & & 8 & \\
\hline Mammals medium size & 5 & & 1 & & 223 & & 325 & \\
\hline Mammals large-medium size & 8 & & 620 & & 318 & & 715 & \\
\hline Mammals large size & 79 & & 93 & & 839 & & 1716 & \\
\hline Fragm. Indet. & 54 & & 2968 & & 58261 & & 105732 & \\
\hline Total indeterminate & 148 & 28.2 & 3719 & 86.5 & 59658 & 98.6 & 108503 & 98 \\
\hline Total & 524 & & 4301 & & 60494 & & 110777 & \\
\hline
\end{tabular}


Ursidae (Ursus arctos, U. spelaeus, U.sp.) RS levels 5 top +7
Ursidae (Ursus arctos, U. spelaeus, U.sp.) RS - levels $5+8$
Ursidae (Ursus arctos, $U$. spelaeus, U.sp.) FC - levels A5-

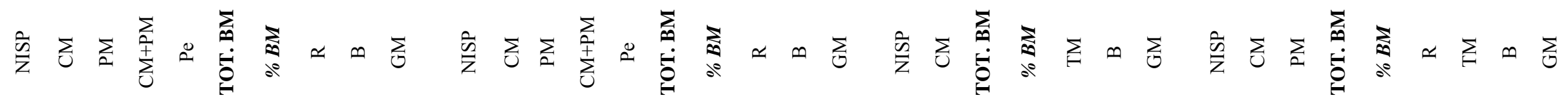

\begin{tabular}{lc}
\hline Cranium & 18 \\
Hemimandible & 13 \\
Tooth indet. & 2 \\
Hyoid & 2 \\
Total cranial & $\mathbf{3 5}$ \\
Atlas-axis & 3
\end{tabular}

Vertebra 12

Rib $54 \quad 10$

Clavicle

Baculum

$\begin{array}{lll}\text { Total axial } & 72 & 10\end{array}$

$\begin{array}{lccccc}6 & 15 & 22 . & 1 & 11 & 10\end{array}$

Scapula

Humerus

Radius

Ulna

Carpals

Metacarpal

$$
3
$$

$\begin{array}{cccccc}3 & & 1 & 1 & 2 & 6 \\ 15 & 6 & 1 & 2 & 9 & 60\end{array}$

$$
43
$$

$$
7
$$

Total frontal limb

$12 \quad 3 \quad 34$

Coxal

Femur

Patella

Tibia

$$
\begin{array}{ccccccc}
44 & 9 & 2 & 3 & & 14 & 31 . \\
8
\end{array}
$$

54

243

\begin{tabular}{cc}
\hline 14 & \\
21 & 1 \\
14 & \\
6 & \\
$\mathbf{5 5}$ & $\mathbf{1}$ \\
2 & \\
21 & 3
\end{tabular}

\section{$\begin{array}{lll}1 & 1 & 4.7\end{array}$}

$\begin{array}{llllll}1 & 1 & 1.8 & 3 & 1 & 4\end{array}$

$\begin{array}{ccc}3 & 14 . & 1\end{array}$

$\begin{array}{cccccc}6 & 15 . & 3 & 1 & 2 & 3\end{array}$

396

1

639

31

31

$\begin{array}{ll}6 & 1\end{array}$
Ursidae (Ursus arctos, U. spelaeus, U.sp.) FC - level A6

\section{)}

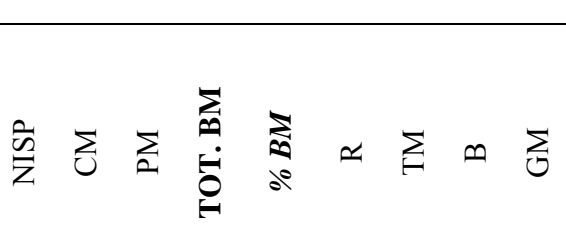




\begin{tabular}{|c|c|c|c|c|c|c|c|c|c|c|c|c|c|c|c|c|c|c|c|c|c|c|c|c|c|c|c|c|c|c|c|c|c|c|c|c|}
\hline Fibula & 4 & & & & & & & & & & 4 & 1 & & & & 1 & 25 & & & & 1 & 1 & 1 & & & & & & & & & & & & & \\
\hline Calcaneum & 2 & & & & & & & & & & & & & & & & & & & & & & & & & & & & & & & & & & & \\
\hline Astragalus & 1 & & & & & & & & & 1 & & & & & & & & & & & & & & & & & & & & & & & & & & \\
\hline Tarsals & 3 & & & & & & & & & & 1 & & & & & & & & & & 2 & 1 & 1 & & & & & 1 & 1 & & 1 & & & & & \\
\hline Metatarsal & 1 & & & & & & & & & & 5 & & & & & & & & & 3 & & & & & & & & 1 & 1 & & 1 & & & & & \\
\hline Total hind limb & 43 & 7 & 3 & 4 & & 14 & $\begin{array}{c}32 . \\
5\end{array}$ & & 3 & 5 & 49 & 8 & 4 & 4 & & 16 & $\begin{array}{c}32 . \\
6\end{array}$ & & 5 & 7 & 3 & 2 & 2 & $\begin{array}{c}66 . \\
6\end{array}$ & & & & 5 & 4 & 1 & 5 & 100 & & 1 & & \\
\hline Metapodial & & & & & & & & & & & 2 & & & & & & & & & & & & & & & & & 2 & & & & & & & & 2 \\
\hline Second phalanx & 8 & & & & & & & & & & 6 & & & & & & & & 1 & 2 & & & & & & & & 3 & 1 & & 1 & & & & 1 & \\
\hline Third phalanx & 6 & & & & & & & & & 1 & 6 & & & & & & & & & & 1 & & & & & & & 4 & & & & & & & & \\
\hline Sesamoid & & & & & & & & & & & 2 & & & & & & & & & & 4 & 1 & 1 & & & 1 & & 3 & 1 & & 1 & & & & 2 & \\
\hline Total distal. limb & 22 & 2 & & & & 2 & 9.1 & & 2 & 1 & 27 & & & & & & & & 1 & 3 & 6 & 2 & 2 & $\begin{array}{c}33 . \\
3\end{array}$ & 1 & 2 & & 13 & 3 & & 3 & 23 & 1 & & 4 & 2 \\
\hline Indet. & 4 & 1 & 1 & & & 2 & 50 & & 1 & & 4 & 2 & & & & 2 & 50 & & 2 & & & & & & & & & & & & & & & & & \\
\hline Tot. & 220 & 29 & 5 & 7 & 6 & 47 & $\begin{array}{r}21 . \\
4 \\
\end{array}$ & 1 & 25 & 20 & 222 & \begin{tabular}{|l|}
2 \\
3 \\
\end{tabular} & 4 & 6 & 1 & 34 & $\begin{array}{c}15 . \\
3 \\
\end{array}$ & 3 & 13 & 15 & 19 & 6 & 6 & 30 & 2 & 4 & 1 & 31 & 8 & 2 & 10 & $\begin{array}{c}32 . \\
2\end{array}$ & 2 & 1 & 4 & 2 \\
\hline
\end{tabular}


Ursidae (Ursus arctos, $U$. spelaeus, $U$. sp.) RS - levels 5 top + 7

\begin{tabular}{ccccc}
\cline { 3 - 4 } NISP & MNE & NEE & $\begin{array}{c}\text { Skeletal } \\
\text { surv. } \\
\text { Rate(\%) }\end{array}$ & $\begin{array}{c}\text { Fragm. } \\
\text { Index } \\
\text { MNE/NISp }\end{array}$ \\
\hline
\end{tabular}

\section{Cranium}

Hemimandible

Tooth indet.

Hyoid

Total cranial

Atlas-axis

Vertebra

Rib

Clavicle

Baculum

\section{Total axial}

Scapula

Humerus

Radius

Ulna

Carpals

Metacarpal

Total frontal

limb

Femur

Patella

Tibia

Fibula

Calcaneum

Astragalus

Tarsals

Metatarsal

Total hind limb

Metapodial

35

2

12

16.6

35.4

$$
\begin{aligned}
& 35.4 \\
& 12.5
\end{aligned}
$$

384

$$
3.1
$$

8.9

0.5

12

12

312

4.1

12$$
16.6
$$

756

24$$
\begin{gathered}
6 \\
4.1
\end{gathered}
$$

4.1$$
12.5
$$$$
41.6
$$$$
\begin{aligned}
& 24 \\
& 24
\end{aligned}
$$

168

120

384

24

$$
16.6
$$$$
4.1
$$$$
10
$$$$
9.6
$$$$
50
$$

$$
24
$$

24
24

25

16.6

16.6

8.3
4.1$$
2.5
$$$$
0.8
$$

43

29

120

120

360

8

0.7

1

1

\begin{tabular}{|c|c|c|c|c|}
\hline NISP & MNE & NEE & $\begin{array}{c}\text { Skeletal } \\
\text { surv. } \\
\text { Rate(\%) }\end{array}$ & $\begin{array}{l}\text { Fragm. } \\
\text { Index } \\
\text { MNE/NISp }\end{array}$ \\
\hline
\end{tabular}

1

1
1
0.6

0.6

Ursidae (Ursus arctos, U. spelaeus, $U$. sp.) RS - levels $5+8$

\begin{tabular}{ccccc} 
& & & Rate(\%) & MNE/NISp \\
\hline 14 & 6 & 16 & 37.5 & 0.4 \\
21 & 13 & 32 & 40.6 & 0.6
\end{tabular}

NISP MNE NEE

$\begin{array}{ccc}3 & 3 & 5 \\ 1 & 1 & 10\end{array}$

Ursidae (Ursus

arctos, $U$.

spelaeus, $U$. sp.)

A5+A6

Ursidae (Ursus

arctos, $U$.

spelaeus, $U$. sp.)

FC - level A6

NISP MNE NEE

$\begin{array}{ccc}3 & 3 & 6 \\ 3 & 3 & 12\end{array}$

14

6

55

6

$\begin{array}{cc}1 & 1 \\ 5 & 5 \\ \mathbf{4 9} & \mathbf{2 8} \\ 2 & 2\end{array}$

$\begin{array}{ccc}16 & 37.5 & 1 \\ \mathbf{6 4} & \mathbf{3 9} & \mathbf{0 . 4} \\ 32 & 6.2 & 1 \\ 512 & 4.1 & 1 \\ 416 & 4.3 & 0.4\end{array}$

22

$\begin{array}{ll}2 & 2 \\ 21 & 21 \\ 39 & 18\end{array}$

$\begin{array}{ccc}1 & 1 & 16 \\ \mathbf{6 3} & \mathbf{4 2} & \mathbf{9 7 6} \\ 3 & 2 & 32 \\ 2 & 1 & 32 \\ 3 & 3 & 32 \\ 6 & 6 & 32 \\ 6 & 6 & 224 \\ 4 & 4 & 160 \\ \mathbf{2 4} & \mathbf{2 2} & \mathbf{5 1 2} \\ 28 & 11 & 32 \\ 1 & 1 & 32 \\ 10 & 7 & 32 \\ 4 & 3 & 32\end{array}$

6.2

4.2

4.1

34.3

3.1

3.1
21.8

9.3

$$
\begin{array}{ccccccc}
1 & & & & & & \\
0.6 & 3 & 3 & 130 & 2 & 2 & 972
\end{array}
$$$$
0.6
$$$$
0.5
$$$$
1
$$$$
1
$$$$
1
$$

0.9$$
0.4
$$$$
\begin{gathered}
1 \\
0.7
\end{gathered}
$$$$
130
$$$$
\begin{array}{llllll}
1 & 1 & 10 & 1 & 1 & 12 \\
1 & 1 & 10 & 1 & 1 & 12
\end{array}
$$$$
1 \quad 1 \quad 70
$$$$
\begin{array}{llllll}
3 & 3 & 90 & 2 & 2 & \mathbf{2 4}
\end{array}
$$

160
160
$\mathbf{4 4 8}$

0.6
3.1
6.2

0.7

1
1
0.5

1
1
0.5

2

$\begin{array}{cccccc}2 & 2 & 20 & 1 & 1 & 60 \\ & & & 1 & 1 & 60 \\ \mathbf{3} & \mathbf{3} & \mathbf{3 0} & \mathbf{5} & \mathbf{5} & \mathbf{1 4 4} \\ & & & 2 & 2 & \end{array}$




\begin{tabular}{|c|c|c|c|c|c|c|c|c|c|c|c|c|c|c|c|c|}
\hline First phalanx & 8 & 8 & 240 & 3.3 & 1 & 11 & 11 & 320 & 3.4 & 1 & 1 & 1 & 100 & 1 & 1 & 120 \\
\hline Second phalanx & 8 & 8 & 192 & 4.2 & 1 & 6 & 6 & 256 & 2.3 & 1 & & & & 3 & 3 & 96 \\
\hline Third phalanx & 6 & 6 & 240 & 2.5 & 1 & 6 & 6 & 320 & 1.8 & 1 & 1 & 1 & 100 & 4 & 4 & 120 \\
\hline Sesamoid & & & & & & 2 & 2 & 640 & & & 4 & 4 & 200 & 3 & 3 & 240 \\
\hline $\begin{array}{l}\text { Total distal } \\
\text { limb }\end{array}$ & 22 & 22 & 672 & 3.3 & 1 & 27 & 27 & 1536 & 3 & 1 & 6 & 6 & 400 & 13 & 13 & 576 \\
\hline Indet. & 4 & & & & & 4 & & & & & & & & & & \\
\hline Tot. & 220 & 153 & 2220 & 6.9 & 0.7 & 222 & 144 & 3536 & 4,1 & 0.6 & 19 & 19 & 665 & 31 & 28 & 1734 \\
\hline
\end{tabular}




\begin{tabular}{ccccccc} 
& \multicolumn{5}{c}{ RS - levels 5 top +7 } \\
\hline \multirow{2}{*}{ Taxa } & NISP & \multicolumn{4}{c}{ MNI by age } & Total MNI \\
\cline { 3 - 5 } & & I & Y & A & S & \\
\hline Ursus arctos & 6 & & & 1 & & $\mathbf{1}$ \\
Ursus spelaeus & 148 & 2 & 2 & 4 & 3 & $\mathbf{1 1}$ \\
Ursus sp. & 66 & 1 & & 1 & & $(2)$ \\
\hline TOT. & $\mathbf{2 2 0}$ & $\mathbf{2}$ & $\mathbf{2}$ & $\mathbf{5}$ & $\mathbf{3}$ & $\mathbf{1 2}$ \\
\hline
\end{tabular}

\begin{tabular}{ccccccc}
\hline \multicolumn{5}{c}{ RS - levels $5+8$} \\
\cline { 2 - 5 } NISP & \multicolumn{4}{c}{ MNI by age } & \\
\cline { 2 - 6 } & I & Y & Y-A & A & S & \\
\hline 1 & & & & 1 & & $\mathbf{1}$ \\
157 & 1 & 2 & 1 & 8 & 3 & $\mathbf{1 5}$ \\
64 & 1 & & 1 & 1 & & $(3)$ \\
\hline $\mathbf{2 2 2}$ & $\mathbf{1}$ & $\mathbf{2}$ & $\mathbf{1}$ & $\mathbf{9}$ & $\mathbf{3}$ & $\mathbf{1 6}$ \\
\hline
\end{tabular}

\begin{tabular}{ccccc}
\hline \multicolumn{4}{c}{$\boldsymbol{F}$ C - levels $\mathbf{A 5 - A 5 + A 6}$} \\
\hline \multirow{2}{*}{ NISP } & \multicolumn{2}{c}{ MNI by age } & \multirow{2}{*}{ Total MNI } \\
\cline { 2 - 4 } & I & Y & A & \\
\hline 4 & & & 1 & $\mathbf{1}$ \\
2 & & & 1 & $\mathbf{1}$ \\
13 & 1 & 2 & 1 & $\mathbf{3}(1)$ \\
\hline $\mathbf{1 9}$ & $\mathbf{1}$ & $\mathbf{2}$ & $\mathbf{2}$ & $\mathbf{5}$ \\
\hline
\end{tabular}

\begin{tabular}{cccccc}
\hline \multicolumn{5}{c}{ FC-level A6 } \\
\cline { 1 - 4 } NISP & \multicolumn{3}{c}{ MNI by age } & Total MNI \\
\cline { 2 - 5 } & I & Y & Y-A & A & \\
\hline 10 & & & 1 & 2 & 3 \\
- & & & & & \\
21 & 2 & 1 & & 1 & $\mathbf{3}(1)$ \\
\hline 31 & $\mathbf{2}$ & $\mathbf{1}$ & $\mathbf{1}$ & $\mathbf{2}$ & $\mathbf{6}$ \\
\hline
\end{tabular}


Table 6

\begin{tabular}{|c|c|c|c|c|c|c|c|c|c|c|c|c|}
\hline $\begin{array}{l}\text { ID } \\
\text { retoucher }\end{array}$ & Site & US & Species & $\begin{array}{c}\text { Anatomical } \\
\text { portion }\end{array}$ & FfrB & $\mathbf{C M}$ & $\mathbf{P M}$ & B & $\mathbf{L}$ (in cm) & Wi (in cm) & $\mathbf{T}$ (in $\mathbf{c m}$ ) & We (in gr) \\
\hline 406 & $\mathrm{RS}$ & 5 top & Ursus spelaeus & Rib frag. & $\mathrm{x}$ & $\mathrm{x}$ & & $\mathrm{x}$ & 8.4 & 1.7 & 1.6 & 12.6 \\
\hline 454 & $\mathrm{RS}$ & 5 & Ursus sp. & Rib frag. & $\mathrm{x}$ & & & & 8.3 & 1.5 & 1.5 & 12.6 \\
\hline 203 & $\mathrm{RS}$ & 7 base $/ 5$ & Ursus spelaeus & Rib frag. & $\mathrm{x}$ & & & $\mathrm{x}$ & 8 & 1.7 & 1.6 & 13 \\
\hline 125 & $\mathrm{RS}$ & 8 & Ursus sp. & Rib frag. & $\mathrm{x}$ & & & & 7.3 & 1.4 & 1.4 & 10.3 \\
\hline 5805 & $\mathrm{FC}$ & A6/A7 & Ursus arctos & Ulna frag. & $\mathrm{x}$ & & $\mathrm{x}$ & & 7 & 2.3 & 1.6 & 20.6 \\
\hline D853 & $\mathrm{FC}$ & A6 & Ursus arctos & Phalanx I & $\mathrm{x}$ & $\mathrm{x}$ & & $\mathrm{x}$ & 4.2 & 2 & 1.1 & 6 \\
\hline
\end{tabular}


Click here to download high resolution image

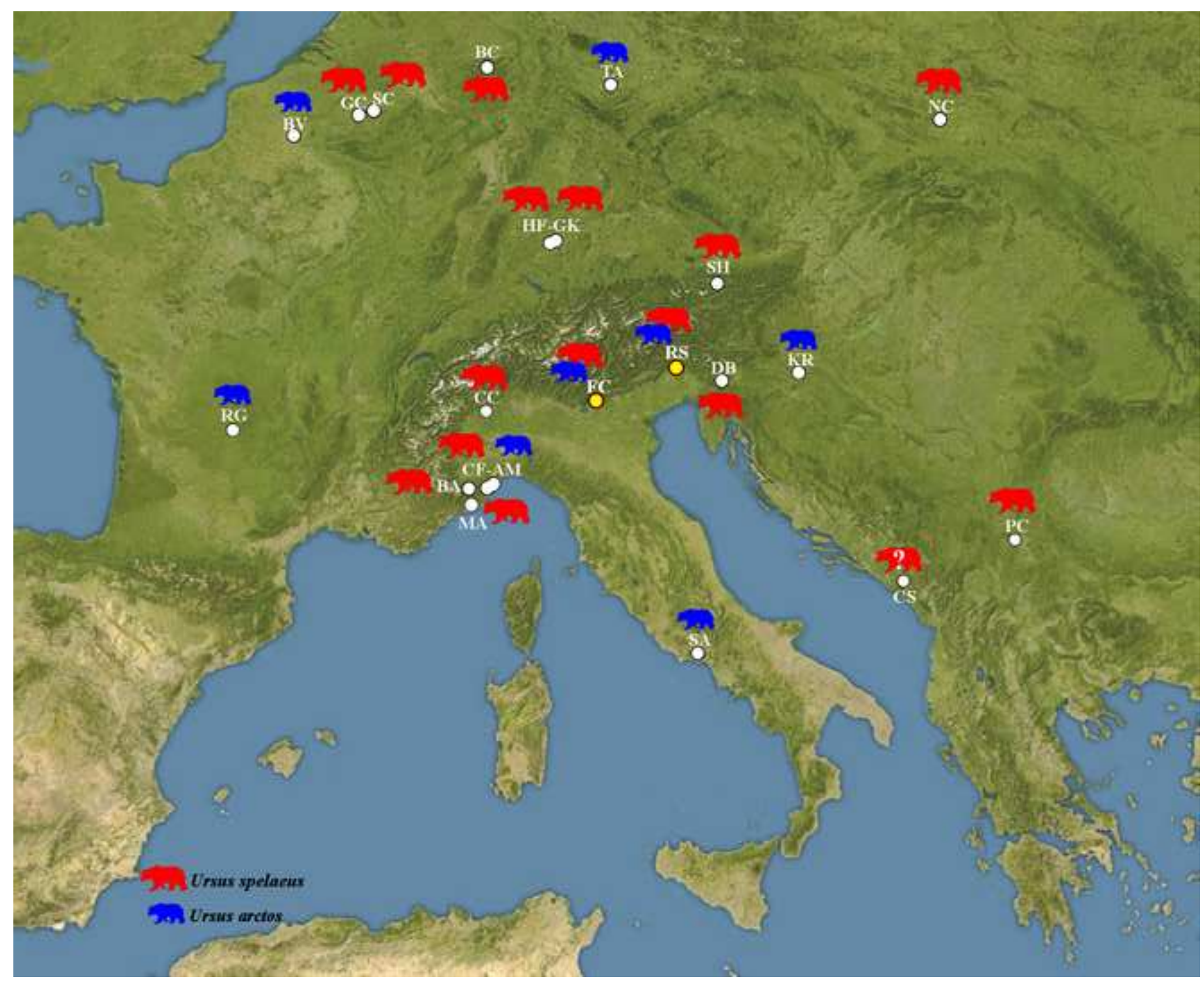


Click here to download high resolution image

.

A

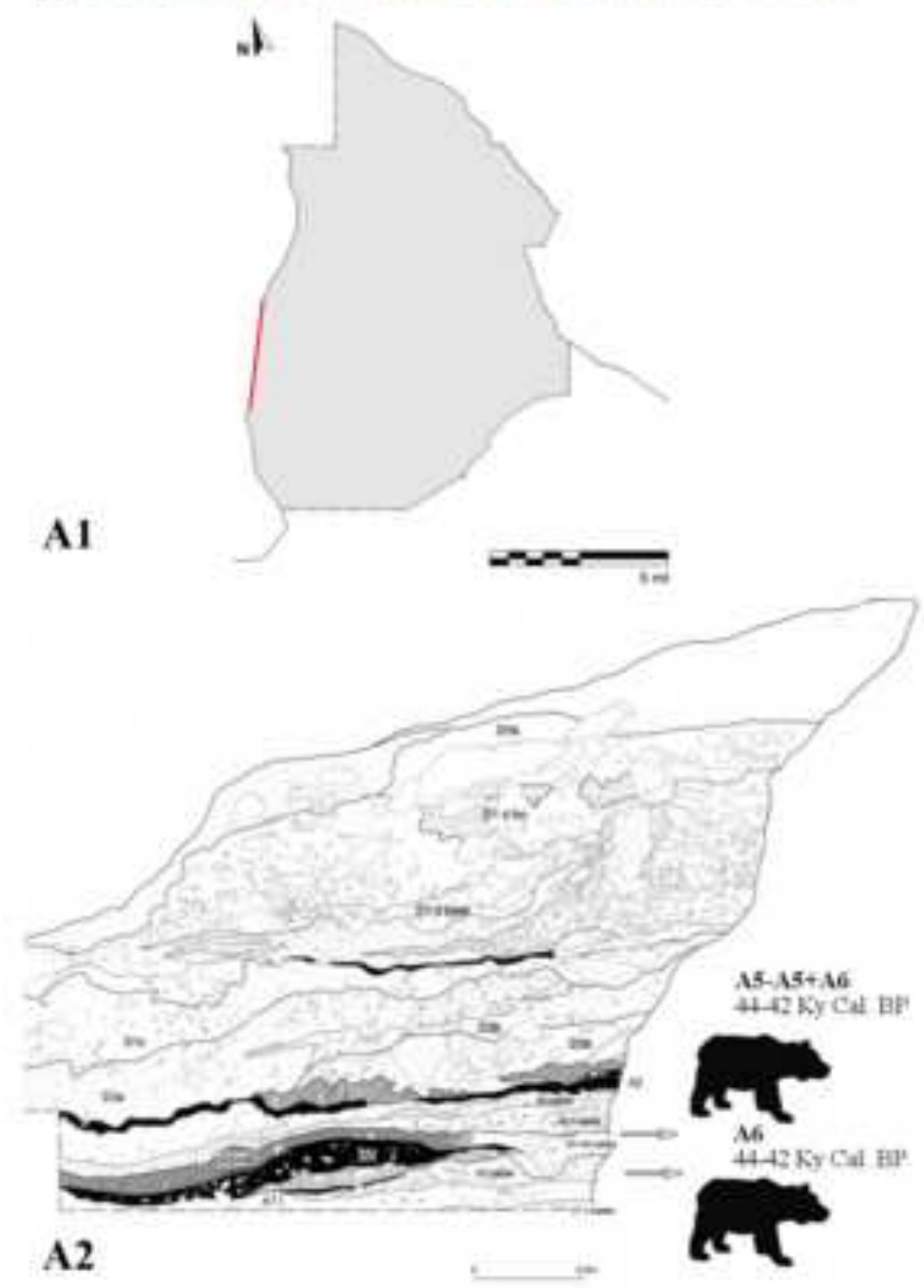

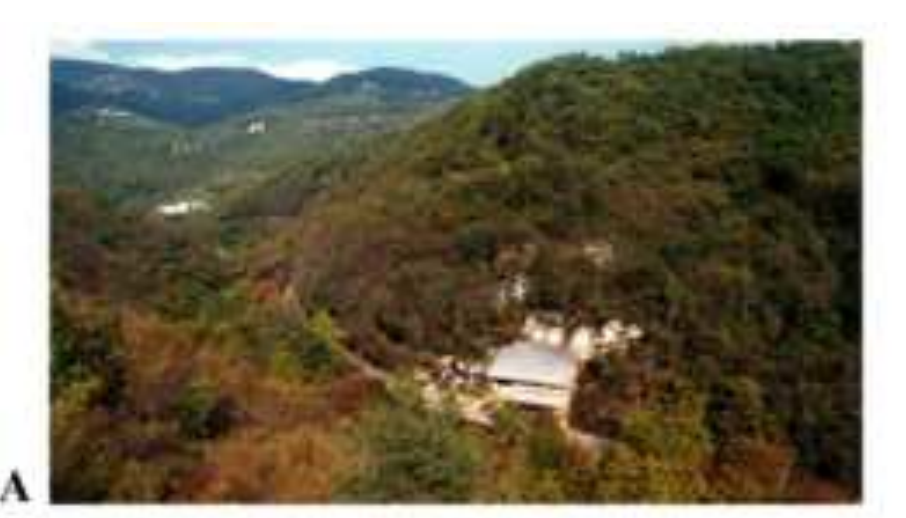

B

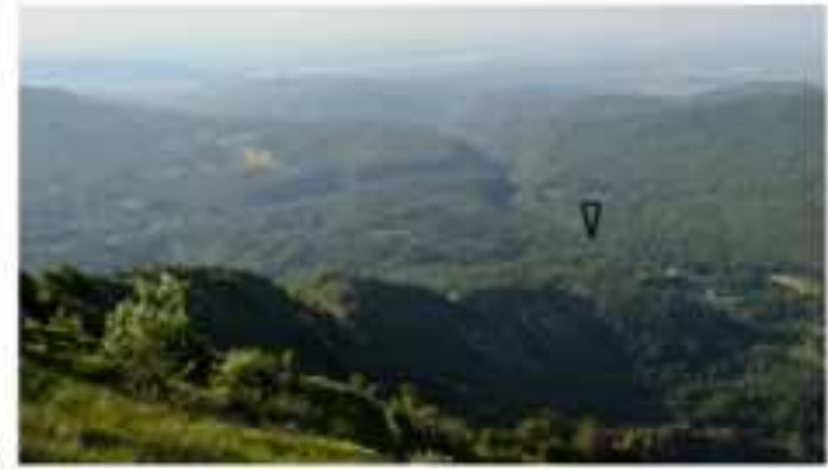

B1 $540 p+7$
$45-35 y c a l$
Bip
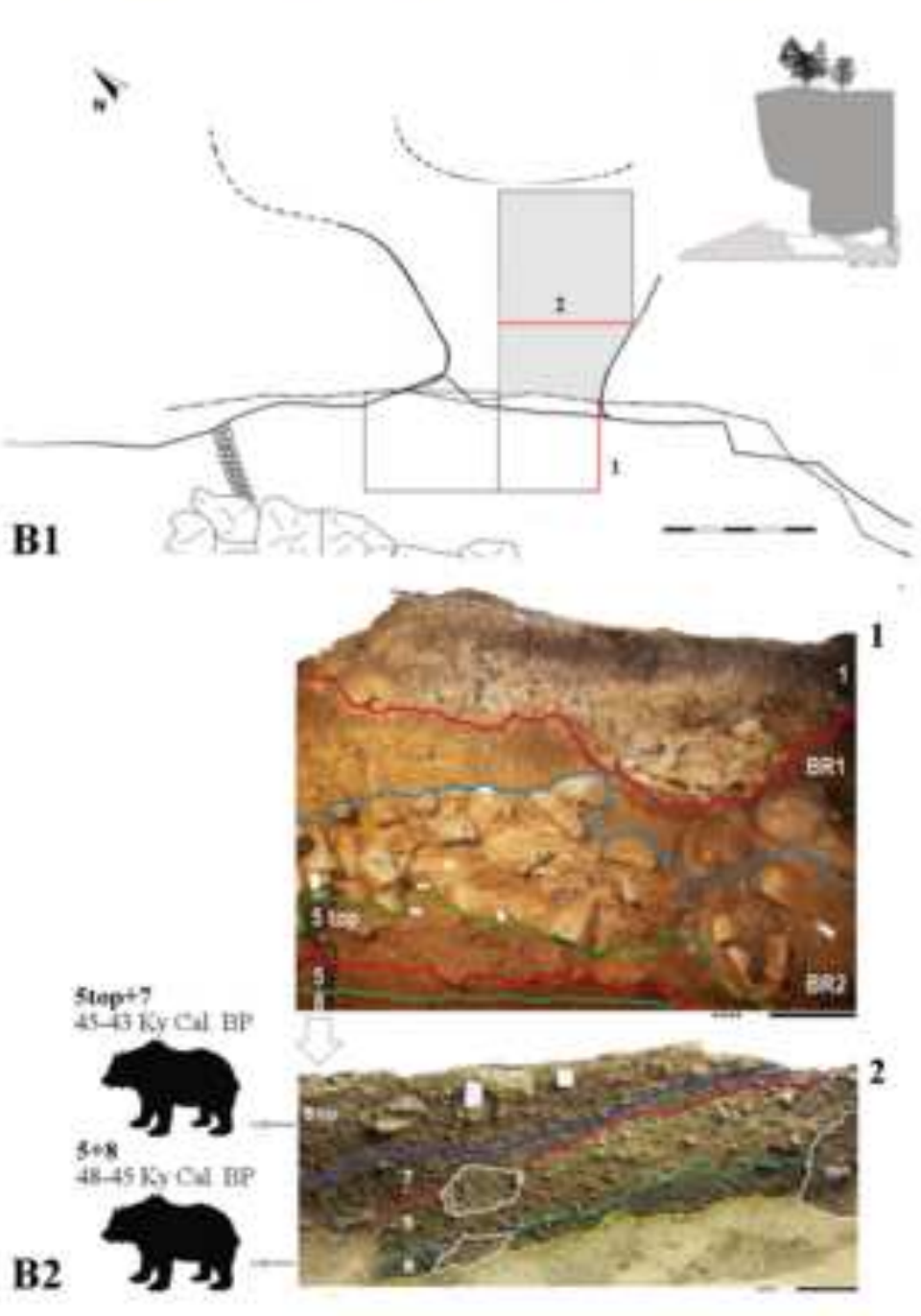

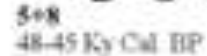




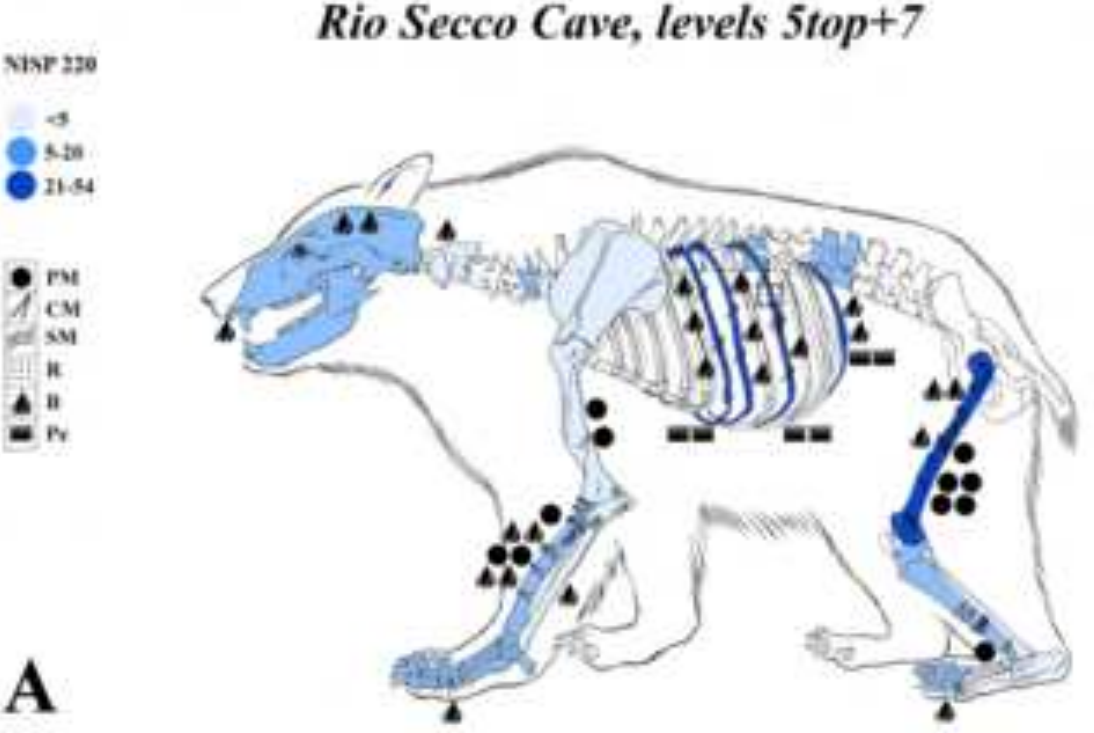

Fumane Cave, levels A5-A5+A6

NISP I9

8 ;

Acs

$4=$

C

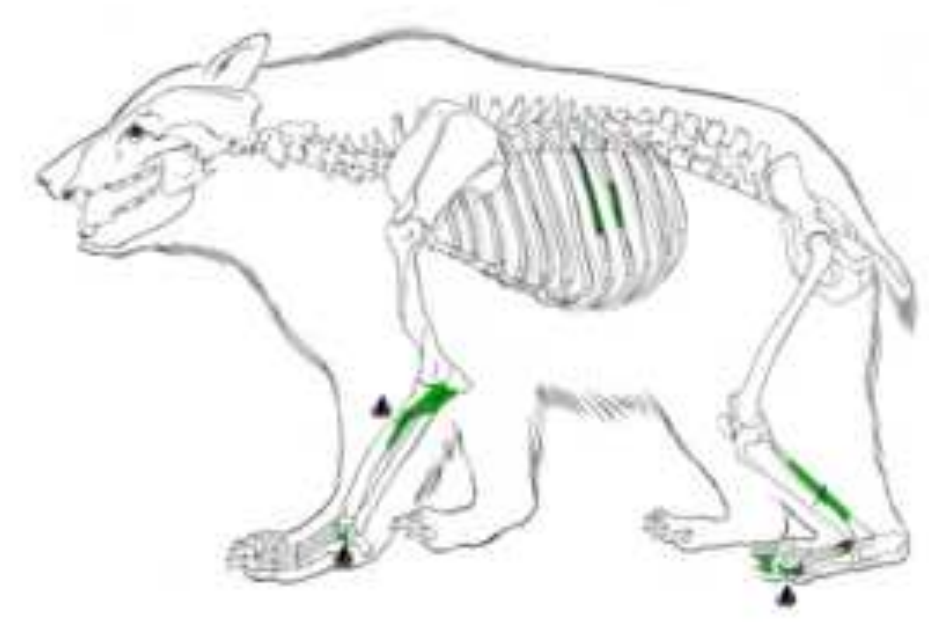

Nerm

Rio Secco Cave, levels $5+8$

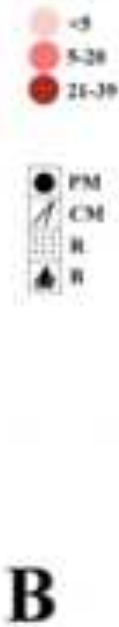

Fumane Cave, level A6

NES
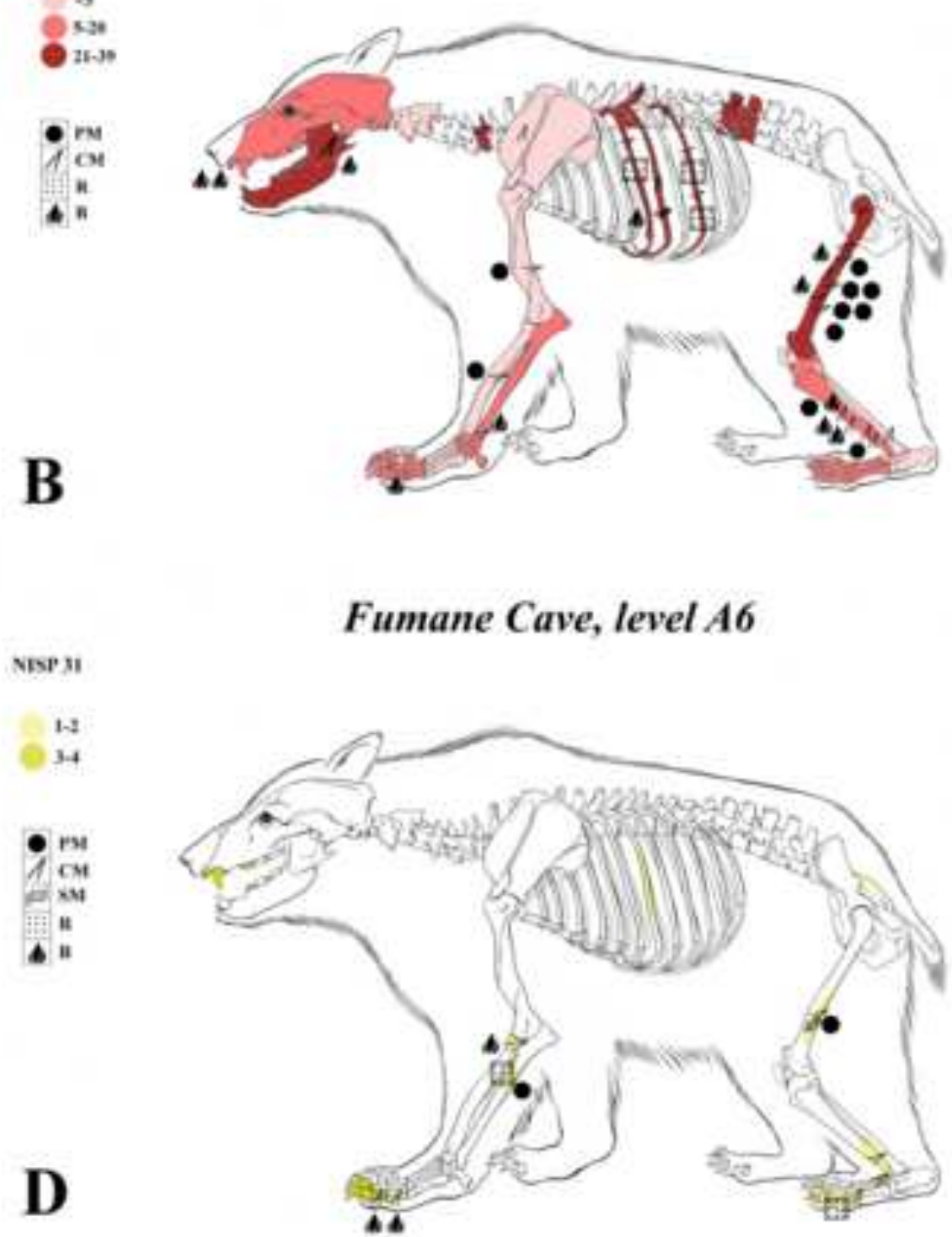

46 


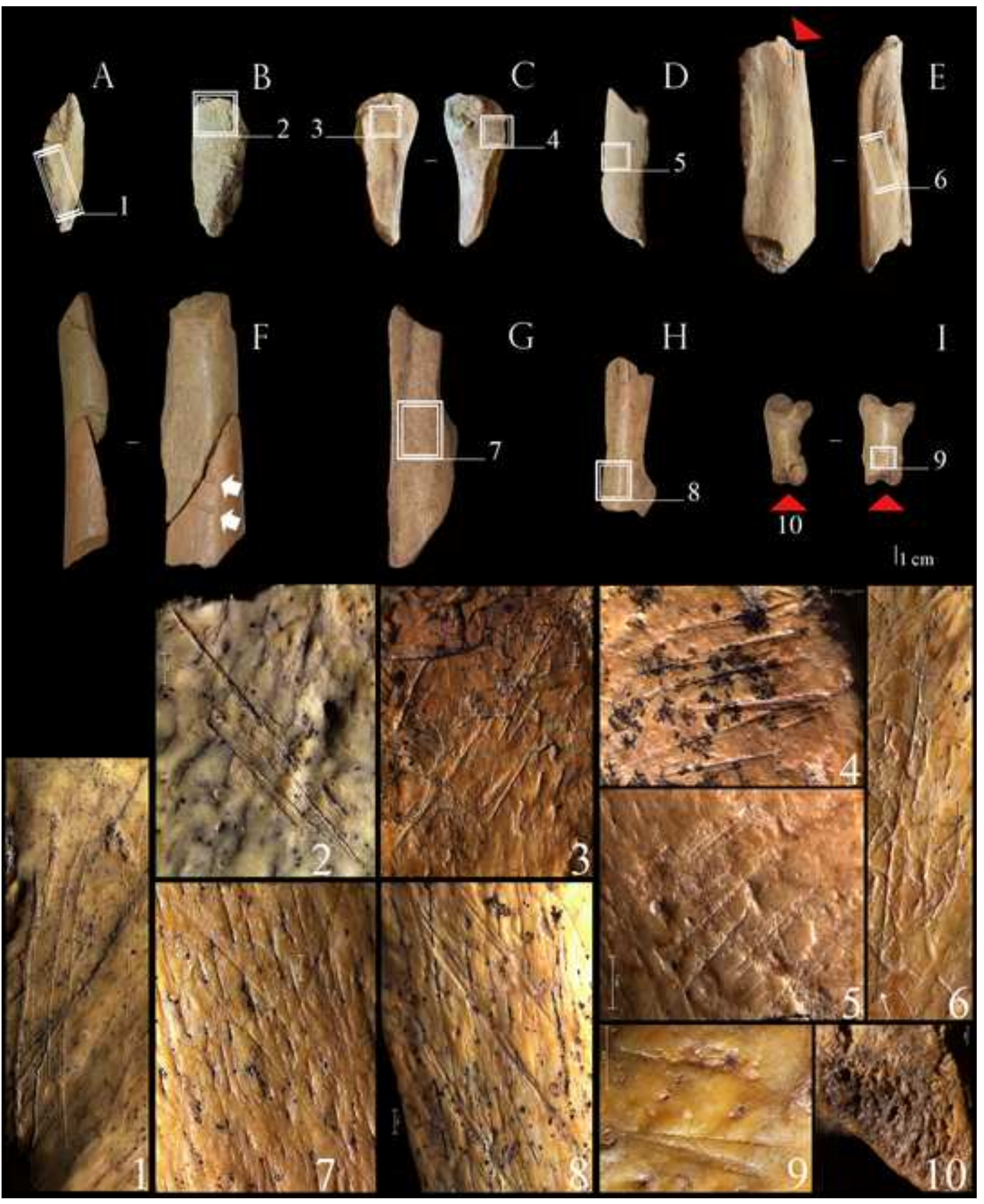


Click here to download high resolution image
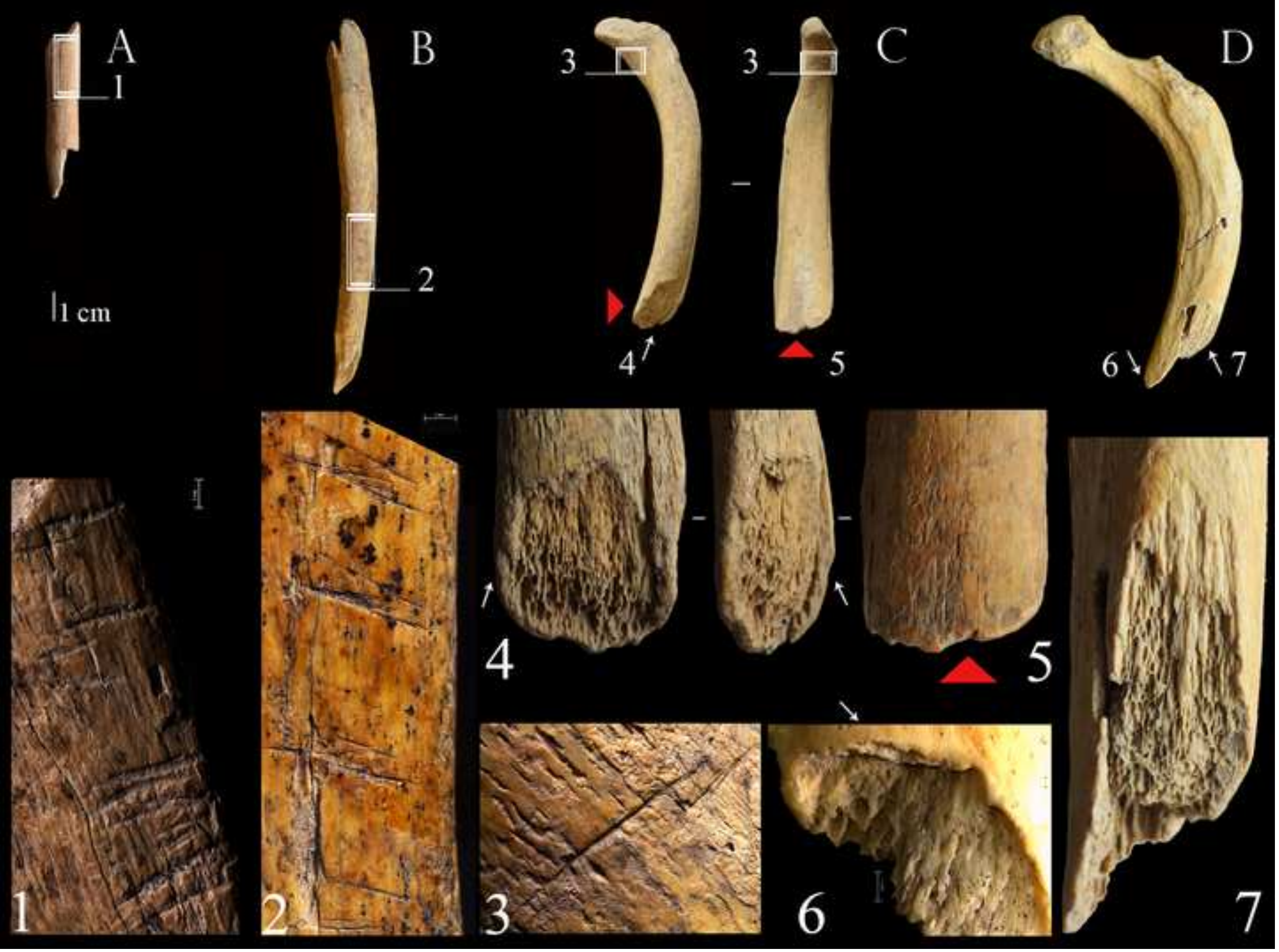


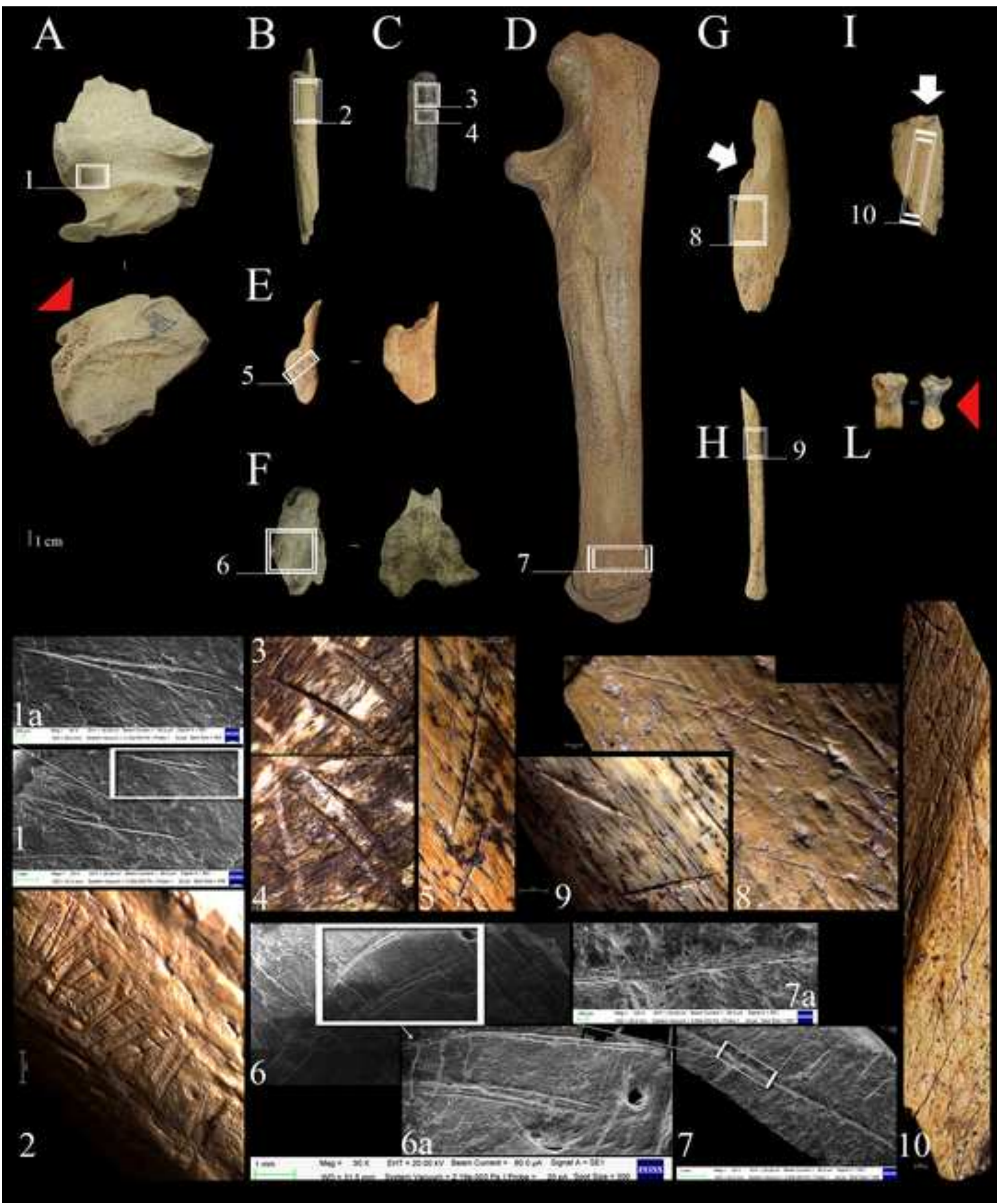



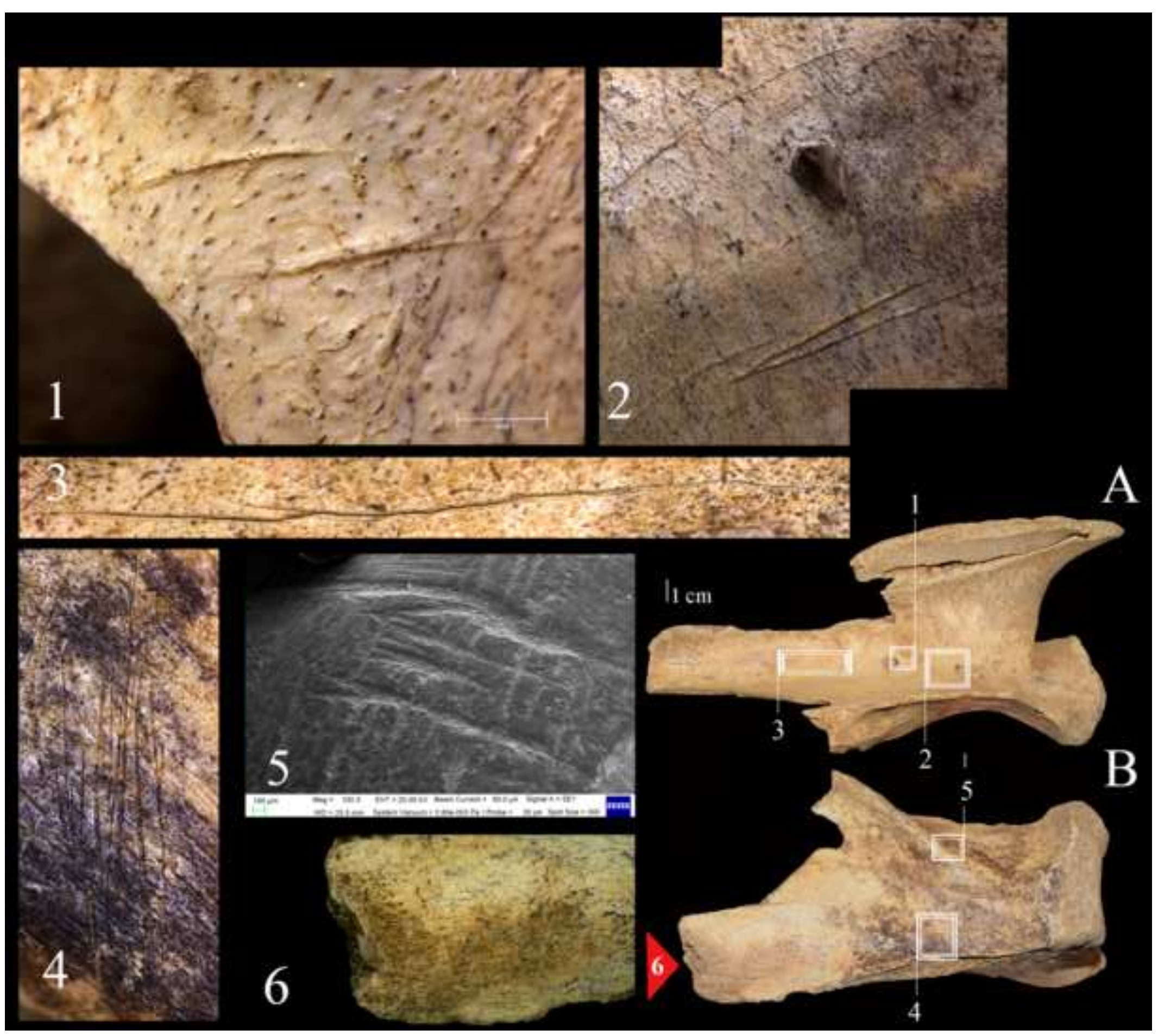


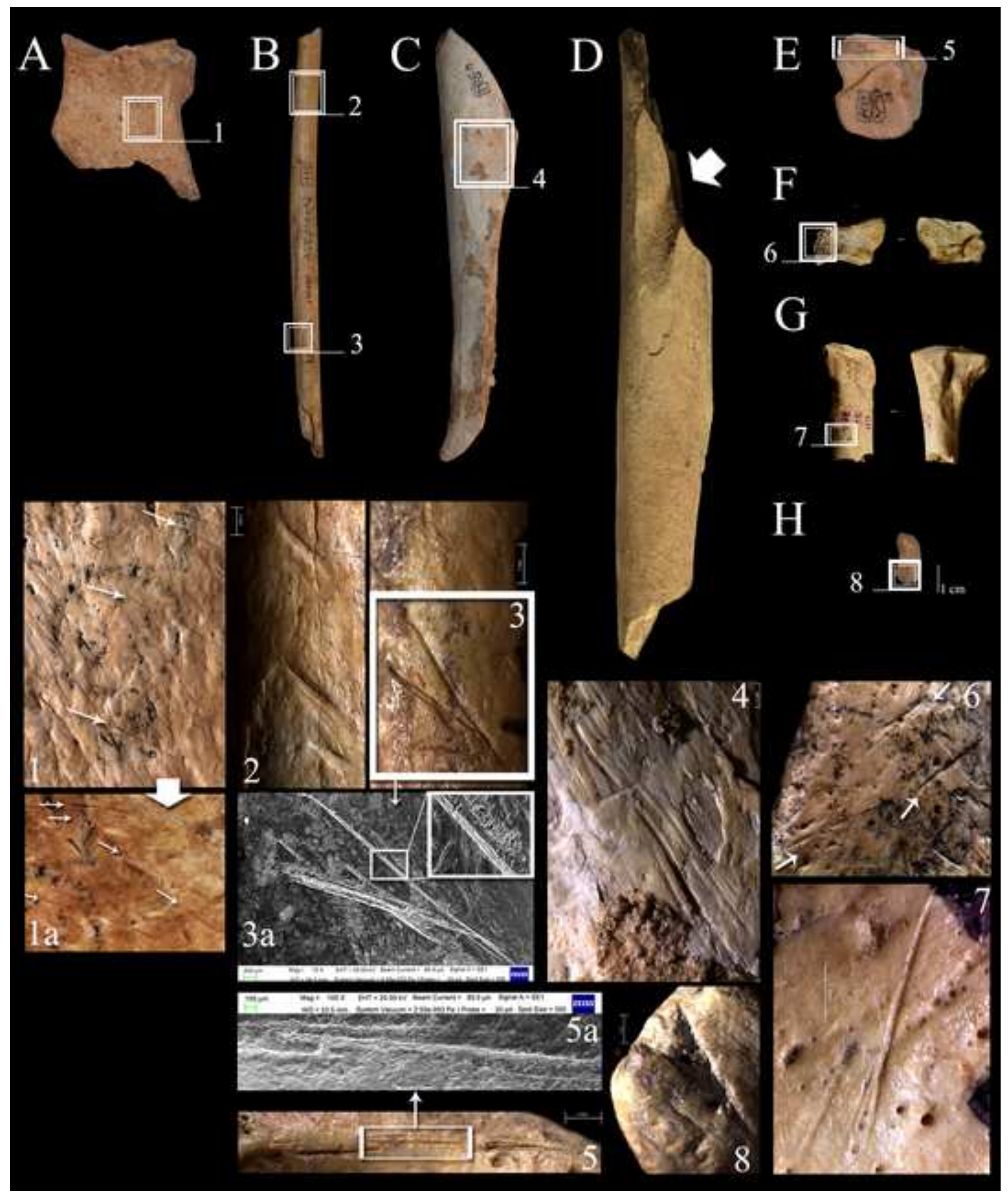


Click here to download high resolution image

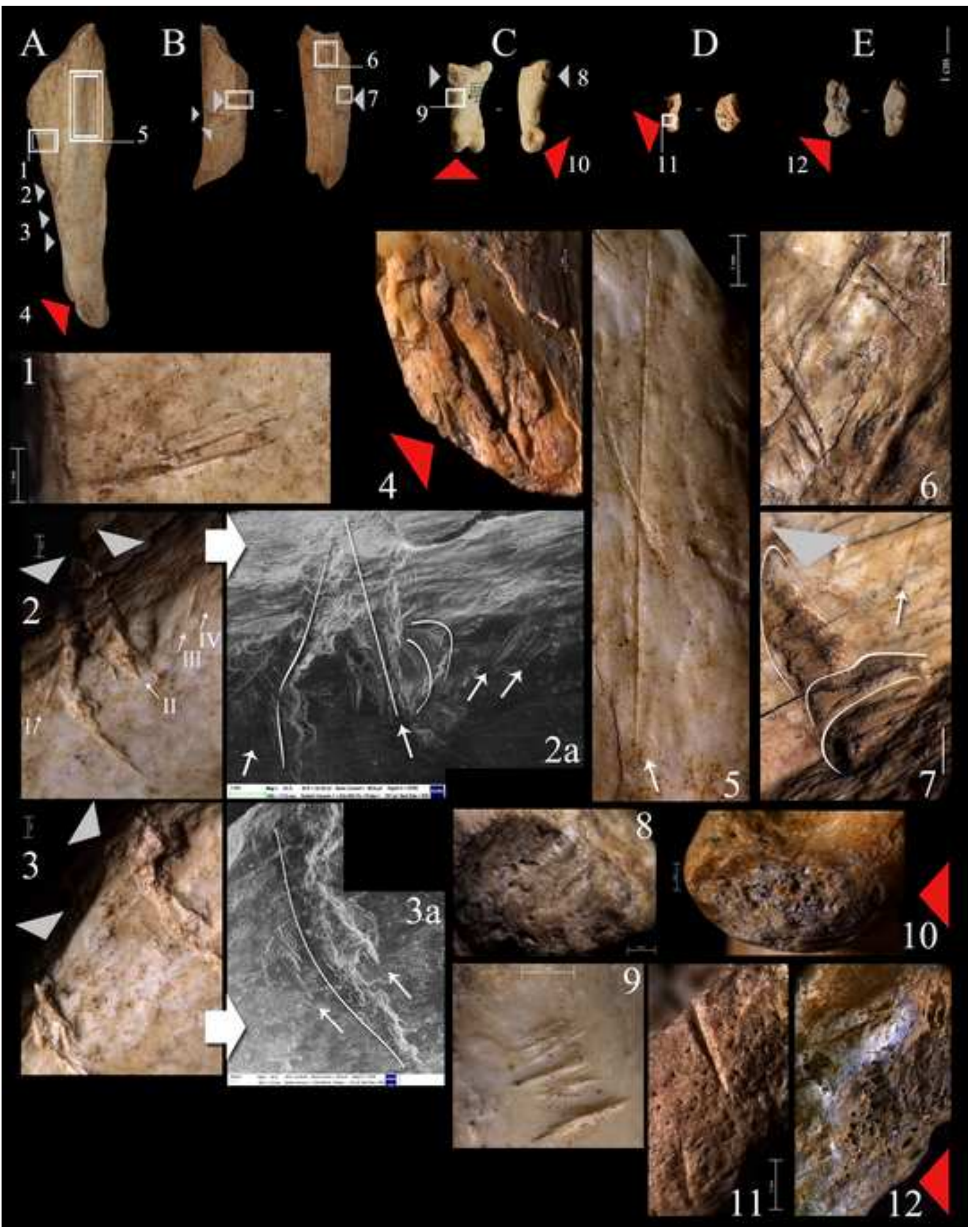




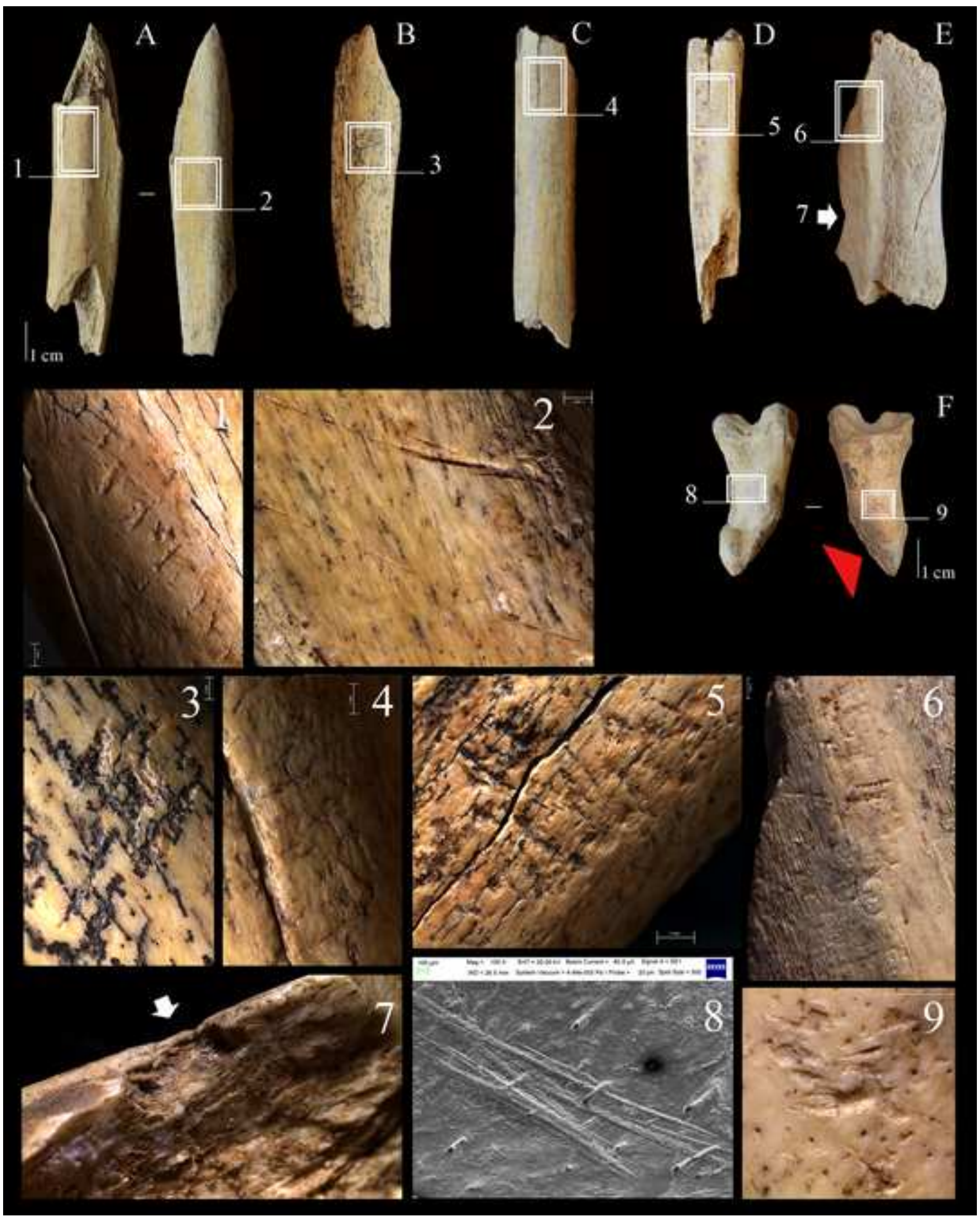


Supplementary Material
Click here to download Supplementary Material: SUPPLEMENTARY MATERIAL.docx

\begin{abstract}
Clik here to download Supplementary Material: SUPPLEMENTARY MATERIALdocX
\end{abstract}
.

pplementary Material: SUP

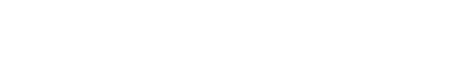

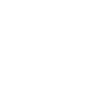

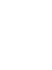

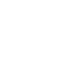

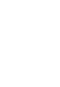

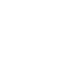

.

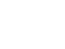

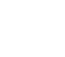

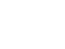
更

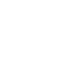

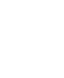

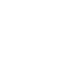
更

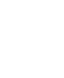

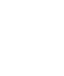

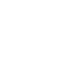

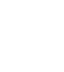

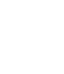

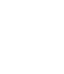

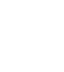

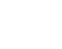


Supplementary Material
Click here to download Supplementary Material: Tab.1-SI.docx

Supplementary Material
Click here to download Supplementary Material: Tab.1-SI.docx

\author{
Click here to download Supplementary Material: Tab.1-SI.docx
}

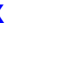

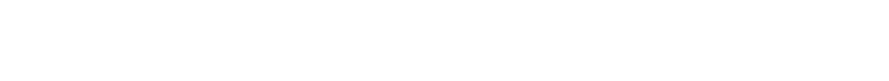

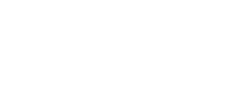

$\sqrt{2}+2$

(a)

(1)

.

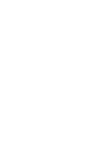

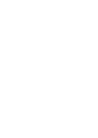

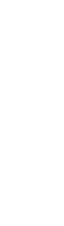

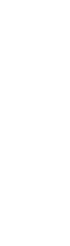

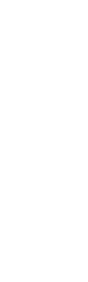

$\left(\frac{10}{0}\right.$

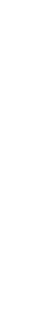

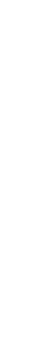

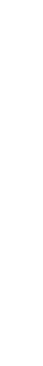

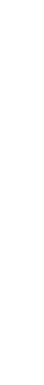

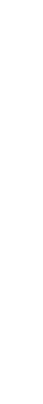




\section{SUPPLEMENTARY INFORMATION}

\section{Short presentation of Rio Secco Cave}

Rio Secco cave is situated in a stream gorge at 580m asl on the Pradis Plateau in the eastern part of the Carnic Pre-Alps, an orographic system dissected by N-S and W-E oriented valleys separating mountains with peaks of 2,000-2,300m asl. The site is a flat and wide south-facing shelter, with a gallery completely filled with sediments, which, in the outer area of the shelter, are limited to a heap of large boulders suggesting that the original roof was larger than in present-day. At the present state of investigations, no claw marks on the walls or polish walls ascribable to bears have been detected. Discovered in 2002 and systematically investigated since 2010, the cavity contains a sedimentary succession made of stones and loams that records human occupations during the Middle Palaeolithic (layers 5top, 7, 5, and 8) and Upper Palaeolithic (layers 6 and 4) (Peresani et al., 2014). The Mousterian assemblages are characterized by the use of Levallois and Discoid technologies. The Upper Palaeolithic of layer 6 consists of a handful of pieces technologically characterized by blade/bladelet production, attributed to Gravettian culture (Peresani et al., 2014; Talamo et al., 2014). Evidence for the use of fire has been found in Mousterian layers ( 8 and 7) in tiny dispersed charcoals, burnt bones, and heat-affected flints. In layer 6, two hearths have been identified, which are partially affected by post-depositional disturbances and labeled US6_SI and US6_SII. The former is an agglomeration of charcoals, mostly disaggregated, around a large piece of charred wood.

The chronometry of layers 7 and 8 show that a lower calibrated boundary cannot be older than 49,000 14C BP, whereas the upper boundary of layer 7 ranges from 49,120 to 47,940 cal BP; the layer 5top ranges from 47,940 to 45,840 cal BP (Talamo et al., 2014).

The zooarchaeological context

Each stratigraphic unit contained animal bone remains. The colonization of the cave fill by marmots is clearly documented by diagnostic signatures that are observed in the upper levels, including dens, chambers, and an articulated skeleton. The faunal remains of the Mousterian sequence record the predominance of carnivores (Ursus arctos, Ursus spelaeus, mustelids, and canids) over ungulates. Amongst the latter, the most abundant species are the cervids (Megaloceros giganteus, Cervus elaphus, Alces alces), followed by caprids (chamois and ibex), wild boar, Sus scrofa, and bovids (Bos/Bison) (Tab. 1). Human interest in ungulates is evidenced by cut-marks on red deer bones. Also, the remains of Ursus spelaeus and Ursus sp. from layers 7 and 5top show traces of butchering, skinning, and the deliberate fracturing of long bones (Peresani et al. 2014; Romandini et al., 2013). 
Bird remains are rare, but appear well conserved, and come from layers 5top, 5, and 8; notable is a terminal pedal phalanx of a cfr. golden eagle from layer 7 that shows anthropic traces on the proximal articular facet (Romandini et al., 2014). In general, in the Mousterian layers, numerous faunal remains show combustion traces (n.700): 93\% are indeterminate bones; 5,6\% Ursidae; 1,1\% Ungulata (Alces alces, Megaloceros giganteus, Bos/Megaloceros, Capra ibex); 0,2\% Carnivora.

This faunal association with cervids and, in particular, deer, elk, roe deer, and wild boar is indicative of forest vegetation and a marsh environment somewhere in the Pradis Plateau. The presence of bovids and caprids suggests the existence of patchy woodland compatible with a mountain context.

\section{Short presentation of Fumane cave}

Fumane cave is located at $350 \mathrm{~m}$ asl in the western part of the Lessini Mountains (Veneto pre-Alps, northern Italy) and has provided a dated sequence spanning from marine isotope stages (MIS) 5 to 2 (Martini et al., 2001; Peresani et al., 2008; Higham et al., 2009). Three tunnels, a main one and two small galleries conjoin in a zone of the cave entrance where the originary wall of a more extended shelter is still visible. At the present state of investigations, no claw marks on the walls or polish walls ascribable to bears have been detected.

At Fumane, the Late Middle-Early Upper Palaeolithic deposits consist of numerous thin to very thin parallel levels and lenses that are grouped into stratigraphic units labeled from bottom to top A13 to A1. Mousterian industries are found in A12-A11, A10, A9, A6-A5, Uluzzian in A4 and A3, and Aurignacian in A2 and A1 (Broglio et al., 2006; Peresani, 2012; Peresani et al., 2011a-b; 2016). The Mousterian levels, which were investigated over areas varying from 6 to $75 \mathrm{sqm}$ in size, are characterized by lithic and faunal remains that are densely scattered on the living floors, as is the case in units A11, A10, A9 and A6. Flints in A12-A11, A10V, A10, and A6-A5 were exploited mostly through Levallois technology (Peresani, 2012; Peresani et al., 2013).

The focus of this paper is the stratigraphic complex A5-A6, dated to 44.8-42.2 ky cal B.P. (Higham et al., 2009). Faunal remains and lithic artifacts are referable to site occupations shifting from intense and persistent (A6) to more ephemeral (A5-A5+A6). Of these levels, A6 in particular has provided evidence of a well-structured use of the living spaces, covering the whole entrance area (Peresani et al., 2011a). Over 40 combustion structures and dumps of combustion debris are associated with zones used for Levallois manufacture, tool shaping and curation, ungulate butchery, and the treatment of hides and furs. 
The zooarchaeological context

The faunal assemblage includes a rich association of ungulates, carnivores, and birds from diverse environments and climates. Quantitative comparison between the faunal associations from the Uluzzian assemblage (A3 and A4) (Tagliacozzo et al., 2013) and the final Mousterian (A5-A6) (Peresani et al., 2011a) has highlighted modest ecological and economic adjustments organized within a humid forest type landscape. Considerable changes are seen in the early Aurignacian occupations (A2), coinciding with the environmental change to a cold type steppe (Cassoli and Tagliacozzo, 1994; Fiore et al., 2004). The underlying level A9 with Discoid technology is notably ecologically analogous with A5 and A6 (Romandini et al., 2014), where the most abundant faunal remains are red deer, ibex, and roe deer, whereas chamois, bison, and giant deer are less frequent. Moose, horse, and wild boar are rare (Tab. 1). All ungulate species, with the exception of horse and wild boar, bear traces of human exploitation. Tibias, femurs and metapodials, radii and humeri from Cervids (red deer, roe deer, and very large specimens of giant deer or elk), and to a lesser extent from other ungulates, were used as retouchers. Fox, wolf, and brown bear and cave bear are the most numerous carnivores (Tab. 1). The current state of research shows the complex A5-A6 to be unique within the entire stratigraphic sequence due to evidence for attention to the treatment of carnivore carcasses. With the exception of wolves, carnivore remains show butchery marks from skinning and defleshing. This data, together with the scarcity of carnivore gnawing on bones and an elevated number of anthropically modified bones, supports the anthropic nature of the bone accumulation in these layer (Peresani et al., 2011a). In addition to the butchery marks on ungulate and carnivore bones, we also report on the discovery of human modifications to some anatomical elements of large raptors and Passeriformes (Peresani et al., 2011b).

\section{References}

Broglio, A., Tagliacozzo, A., De Stefani, M., Gurioli, F., Facciolo, A., 2006. Aurignacian dwelling structures, hunting strategies and seasonality in the Fumane Cave (Lessini Mountains). In: The Early Upper Palaeolithic of Eurasia: general trends, local developments. State Archaeological Museumreserve "Kostenki", 263-268.

Cassoli, P.F., Tagliacozzo, A., 1994. Considerazioni paleontologiche, paleoeconomiche e archeozoologiche sui macromammiferi e gli uccelli dei livelli del Pleistocene superiore del Riparo di Fumane (VR) (Scavi 1988-91). Bollettino Museo Civico di Storia Naturale di Verona 18, 349-445. 
Fiore, I., Gala, M., Tagliacozzo, A., 2004. Ecology and subsistence strategies in the Eastern Italian Alps during the Middle Palaeolithic. International Journal of Osteoarchaeology 14, 273-286.

Higham, T., Brock, F., Peresani, M., Broglio, A., Wood, R., Douka, K., 2009. Problems with radiocarbon dating the Middle to Upper Palaeolithic transition in Italy. Quat. Sci. Rev. 28, 1257-1267. Martini, M., Sibilia, M., Croci, S., Cremaschi, M., 2001. Thermoluminescence (TL) dating opf burnt flints: problems, perspectives and some example of application. Journal of Cultural Heritage 2, 179190.

Peresani, M., 2012. Fifty thousand years of flint knapping and tool shaping across the Mousterian and Uluzzian sequence of Fumane cave. Quat. Int. 247, 125-150.

Peresani M., Centi Di Taranto L.E., 2013. Blades, bladelets and flakes: a case of variability in tool design at the onset of the Middle - Upper Palaeolithic transition in Italy. Comptes Rendus Palevol, 12/4, 211-221.

Peresani, M., Chrzavzez, J., Danti, A., de March, M., Duches, R., Gurioli, F., Muratori, S., Romandini, M., Trombino, L., Tagliacozzo, A., 2011a. Fire-places, frequentations and the environmental setting of the final Mousterian at Grotta di Fumane, a report from the 2006-2008 research. Quartär 58, 131151.

Peresani, M., Cremaschi, M., Ferraro, F., Falguères, C., Bahain, J.J., Gruppioni, G., Sibilia, E., Quarta, G., Calcagnile, L., Dolo, J.M., 2008. Age of the final Middle Palaeolithic and Uluzzian levels at Fumane Cave, northern Italy, using 14C, ESR, 234U/230Th and thermoluminescence methods. J. Archaeol. Sci. 35, 2986-2996.

Peresani, M., Cristiani, E., Romandini, M., 2016. The Uluzzian technology of Grotta di Fumane and its implication for reconstructing cultural dynamics in the Middle - Upper Palaeolithic transition of Western Eurasia. J. Hum. Evo. 91, 36-56.

Peresani, M., Fiore, I., Gala, M., Romandini, M., Tagliacozzo, A., 2011b. Late Neandertals and the intentional removal of feathers as evidenced from bird bone taphonomy at Fumane cave 44ky BP, Italy. PNAS 108, 3888-3893

Peresani, M., Romandini, M., Duches, R., Jéquier, C., Nannini, N., Pastors, A., Picin, A., Schmidt, I., Vaquero, M., Weniger, G. C., 2014. New evidence for the Neanderthal demise and earliest Gravettian occurrences at Rio Secco Cave, Italy. J. F. Archaeol. 39, 401-416.

Romandini M., Nannini N., Tagliacozzo A., Peresani M., 2014. The Ungulate Assemblage from Layer A at Grotta di Fumane, Italy: A Zooarchaeological Contribution to the Reconstruction of Neanderthal Ecology. Quaternary International, 337: 11-27. 
Romandini, M., Nannini, N., Tagliacozzo, A., Peresani, M., 2013. Hunting bear during the Late Mousterian. Evidence from the North of Italy. ESHE Proceedings, 3rd Meeting, 189.

Romandini, M., Peresani, M., Laroulandie, V., Metz, L., Pastoors, A., Vaquero, M., Slimak, L., 2014. Convergent evidence of eagle talons used by Late Neanderthals in Europe: a further assessment on symbolism. PLoS ONE 9(7), e101278.

Tagliacozzo, A., Romandini, M., Fiore, I., Gala, M., Peresani, M., 2013. Animal exploitation strategies during the Uluzzian at Grotta di Fumane (Verona), in: Clark, J.L., Speth J.D. (Eds.), Zooarchaeology and Modern Human Origins: Human Hunting Behavior during the Later Pleistocene. Vertebrate Paleobiology and Paleoanthropology Series, Springer Science, New York, pp. 129-150.

Talamo, S., Peresani, M., Romandini, M., Duches, R., Jéquier, C., Nannini, N., Pastors, A., Picin, A., Vaquero, M., Weninger, G. C., Hublin, J. J., 2014. Detecting human presence at the border of the northeastern Italian Pre-Alps. 14C dating at Rio Secco Cave as expression of the first Gravettian and the late Mousterian in the northern Adriatic region. Plos ONE 9(4), e95376. 


\begin{tabular}{|c|c|c|c|c|c|c|c|c|c|c|c|c|c|c|c|c|}
\hline & \multicolumn{4}{|c|}{$\begin{array}{c}\text { Ursidae (Ursus arctos, } U \text {. spelaeus, } U . \text { sp.) } \\
\text { RS - levels } 5 \text { top }+7\end{array}$} & \multicolumn{4}{|c|}{$\begin{array}{c}\text { Ursidae (Ursus arctos, } U \text {. spelaeus, } U \text {. sp.) } \\
\text { FC - levels A5-A5+A6 }\end{array}$} & \multicolumn{4}{|c|}{$\begin{array}{c}\text { Ursidae (Ursus arctos, U. spelaeus, U. sp.) } \\
\text { FC - levels A5-A5+ A6 }\end{array}$} & \multicolumn{4}{|c|}{$\begin{array}{c}\text { Ursidae (Ursus arctos, U. spelaeus, U. sp.) } \\
\text { FC - level A6 }\end{array}$} \\
\hline & \multirow[t]{2}{*}{ NISP } & \multicolumn{3}{|c|}{ MNI } & \multirow[t]{2}{*}{ NISP } & \multicolumn{3}{|c|}{ MNI } & \multirow[t]{2}{*}{ NISP } & \multicolumn{3}{|c|}{ MNI } & \multirow[t]{2}{*}{ NISP } & \multicolumn{3}{|c|}{ MNI } \\
\hline & & $U . \operatorname{arctos}$ & U.spelaeus & $U$. sp. & & U. arctos & U.spelaeus & $U$. sp. & & U. arctos & U.spelaeus & $U$.sp. & & U. arctos & U.spelaeus & $U$.sp. \\
\hline Cranium & 18 & 1 & 5 & & 14 & & 6 & & 3 & & & 2 & 3 & & & 2 \\
\hline Hemimandible & 13 & & 5 & & 21 & 1 & 10 & 2 & 1 & & & 1 & 3 & & & 1 \\
\hline Tooth indet. & 2 & & 2 & & 14 & & 5 & & & & & & 3 & & & 2 \\
\hline Hyoid & 2 & & 1 & & 6 & & 5 & 1 & & & & & & & & \\
\hline Atlas-axis & 3 & & 1 & & 2 & & 2 & & & & & & & & & \\
\hline Vertebra & 12 & & 4 & & 21 & & 4 & 1 & & & & & 1 & & & 1 \\
\hline Rib & 54 & 1 & 5 & 2 & 39 & & 5 & 3 & 3 & & 1 & 2 & 1 & & & 1 \\
\hline Clavicle & 1 & & 1 & & & & & & & & & & & & & \\
\hline Baculum & 2 & & 2 & & 1 & & & 1 & & & & & & & & \\
\hline Scapula & 3 & & 1 & & 3 & & & & & & & & & & & \\
\hline Humerus & 3 & & 2 & 1 & 2 & & 2 & & & & & & & & & \\
\hline Radius & 15 & 1 & 3 & 2 & 3 & & 2 & 1 & 1 & & & 1 & 1 & 1 & & 1 \\
\hline Ulna & 4 & 1 & 2 & & 6 & & 4 & & 1 & & & & 1 & & & \\
\hline Carpals & 7 & & 2 & & 6 & & 2 & & 1 & & 1 & & & & & \\
\hline Metacarpal & 12 & & 5 & 1 & 4 & & 3 & & & & & & & & & \\
\hline Femur & 24 & & 7 & 1 & 28 & & 6 & 1 & & & & & 2 & 2 & & \\
\hline Patella & & & & & 1 & & 1 & & & & & & & & & \\
\hline Tibia & 8 & & 4 & 1 & 10 & & 4 & 2 & & & & & 1 & & & 1 \\
\hline Fibula & 4 & & 4 & & 4 & & 2 & 1 & 1 & 1 & 1 & & & & & \\
\hline Calcaneum & 2 & & 2 & & & & & & & & & & & & & \\
\hline Astragalus & 1 & & & & & & & & & & & & & & & \\
\hline Tarsals & 3 & & 3 & & 1 & & 1 & & 2 & & & 1 & 1 & 1 & & \\
\hline Metatarsal & 1 & 1 & & & 5 & & 2 & 1 & & & & & 1 & 1 & & \\
\hline Metapodial & & & & & 2 & & & 1 & & & & & 2 & 1 & & 1 \\
\hline First phalanx & 8 & 1 & 2 & & 11 & & 4 & 2 & 1 & 1 & & & 1 & 1 & & \\
\hline Second phalan. & 8 & & 3 & & 6 & & 5 & & & & & & 3 & 1 & & 1 \\
\hline Third phalanx & 6 & & 3 & & 6 & & 2 & 1 & 1 & & & 1 & 4 & 1 & & 1 \\
\hline Sesamoid & & & & & 2 & & & 2 & 4 & & & 2 & 3 & 1 & & 2 \\
\hline Tot. NISP & 220 & & & & 222 & & & & 19 & & & & 31 & & & \\
\hline Tot. MNI & & & 12 & & & & 16 & & & & 5 & & & & 6 & \\
\hline
\end{tabular}

